(C) 2017, Elsevier. Licensed under the Creative Commons Attribution-NonCommercial-NoDerivatives 4.0 International http://creativecommons.org/licenses/by-nc-nd/4.0/

\title{
Why did Brexit happen? Using causal mapping to analyse secondary, longitudinal data
}

Duncan Shaw

Alliance Manchester Business School

Humanitarian and Conflict Research Institute (HCRI)

The University of Manchester

H24 Sackville Street Building

Sackville Street

Manchester, M1 3BB, UK.

duncan.shaw-2@manchester.ac.uk

Chris M. Smith

Alliance Manchester Business School

The University of Manchester

G28 Sackville Street Building

Sackville Street

Manchester, M1 3BB, UK.

Christopher.Smith@manchester.ac.uk

Judy Scully

Aston Business School

Aston University

Aston Triangle

Birmingham, B4 7ET, UK.

J.W.Scully@aston.ac.uk 


\section{Why did Brexit happen? Using causal mapping to analyse secondary, longitudinal data}

\section{$\underline{\text { Abstract }}$}

The outcome of the UK's referendum on whether the UK should leave or remain in the European Union (so-called Brexit) came as a jolt to many across Europe. In this paper, we use causal mapping from soft OR to analyse longitudinal data from nine televised Brexit debates spread across the 4 weeks leading up to the referendum. We analyse these causal maps to build one view on why Brexit happened. The maps are analysed for the breadth, depth and consistency of arguments in the debate and, broadly, finds that the Leave campaign focused more consistently on a smaller set of campaign themes, contributed more detail to those themes, and focused on their own core issues rather than being diverted onto Remain strongholds. In contrast, Remain shared more information but across a broader range of themes (meaning they were less consistent), and followed Leave into themes that were clearly not their core battleground. The novelties for soft OR in this paper include: the difficulties of building and validating causal maps from secondary data; new techniques for analysing a group of causal maps to uncover the properties of arguments that spread longitudinally through a campaign; a methodology for a teaching case using publicly availability data; linking the paper, philosophically, to critical realism given the unique dataset. Finally, we identify differences in the Leave and Remain debate campaigns to offer one answer to the question 'Why did Brexit happen?'.

\section{Keywords:}

Brexit; Soft OR; causal mapping; longitudinal analysis; secondary data

\section{Introduction}

On $24^{\text {th }}$ June 2016, the Chief Counting Officer for the UK referendum on whether the UK should leave or remain in the European Union (EU) announced the outcome - that $72 \%$ of eligible voters had cast their vote of whom 17,410,742 had voted for the United Kingdom (UK) to Leave the EU while $16,141,241$ had voted to Remain. Through this result, the majority of voters had conveyed their desire for the UK to leave the EU and so began one of the most turbulent times in living memory in UK politics. The vote on Britain exiting the EU (so-called, Brexit) was widely described as 'the country's biggest decision in more than a generation' ${ }^{1}$. Given the focus of Operational Research (OR) on decision

\footnotetext{
1 Financial Times (2016) Brexit impact on economy, house prices, markets and politics. $6^{\text {th }}$ July. Similar quotes available from the following articles: The UK Government - Why the Government believes that voting to remain in the European Union is the best decision for the UK (undated); The Independent Whatever your views on the EU, make sure you are registered to vote ( $7^{\text {th }}$ June 2016); The Guardian Cameron: EU referendum is a 'once in a generation' decision (23 $3^{\text {rd }}$ February 2016).
} 
making, this paper uses a soft OR modelling approach to offer one contribution to understanding the Brexit decision that voters made.

OR models are typically built before a decision is taken so that decision makers can employ the process and outcomes from the analysis in shaping the decisions (Rosenhead \& Mingers, 2001). The ingredients of a mathematical OR model were not available for the Brexit decision e.g. basic assumptions were not agreed and there was a lack of hard data to analyse. Added to these challenges were that the arguments offered for/against Brexit were subjective and there was a lack of analogues from which to generalise assumptions as no country has been in this situation before. Such complexities provide the conditions for which soft OR methods are suited.

We select the causal mapping method (Ackermann et al, 2014) from soft OR to analyse the arguments provided to voters by opposing sides of the Brexit debate. Causal mapping is a suitable approach to analyse the type of data available because it can be applied to qualitative data collected from individuals and groups (Williams et al, 2003) and it has been applied to analysing secondary data (Eden \& Ackermann, 2004; Barr et al, 1992). Furthermore, the selection of causal mapping technique allowed qualitative content analysis of the data as well as a more descriptive comparison of Leave and Remain campaigns using quantitative measures (Eden, 2004) - which no other Soft OR approach offers. The data we analyse are the arguments offered during the main televised debates from senior campaigners to live studio audiences and these are from (arguably) the foremost channel through which the Leave and Remain campaigns promoted their messages directly to voters. We selected nine debates which attracted widespread media attention and we analysed 10.5 hours of debate to understand differences in debate strategy.

We have four aims for this paper - three present a unique contribution to soft $O R$, with the fourth contributing to understanding the Brexit outcome. First, our 'methodological' aim is to develop and apply analytical techniques to understand the breadth, depth and consistency of debate arguments in the causal maps from longitudinal data. The methodological novelty of this is twofold: the validation needed when using secondary data is challenging as it is not possible to check the content of a map with a speaker; analysing longitudinal data which has not been done before using soft OR methods. Second, our 'replicability' aim is to present an understandable application of analysing causal maps which can be repeated by others. The novelty is in analysing publicly available data which, to our knowledge, has not before been done using soft OR methods as commercial sensitivities often prevent data sharing. Thus, others can replicate our analysis, for example, students as this paper provides an accessible case study for teaching soft OR (Hindle, 2011). Third, our 'philosophical' aim is to understand the implications of this data on adopting a constructivist philosophy which is usually 
applicable to soft OR causal mapping (Mingers, 2000). Fourth, our 'modelling complexity' aim is to apply the new analytical methods to uncover the differences in the campaigns' approaches to the debates. The novelty here is our identification of core differences between the campaigns in that Leave focused on a more consistent and tightly focused set of campaign themes, provided more explanation of those themes, and focused more on their own core issues than Remain - potentially signalling a difference in debate strategy.

The structure of this paper is that we briefly show the suitability of soft OR methods, and causal mapping in particular, to analyse arguments presented in debates. Then we present our analytical approaches, followed by our findings from applying these to the debates. We discuss the lessons from our analysis and revisit our four aims. However, to set the scene we first provide an overview of the pre-Brexit relationship between the UK and the EU as context for the study.

\section{The Brexit referendum}

The EU is currently composed of 28 member states $^{2}$ and thinking about this Union of Europe began before World War II. In the UK, Sir Winston Churchill (Prime Minister 1940-1945 and 1951-1955) had a generally positive view of Europe, stating "I look forward to a United States of Europe, in which the barriers between the nations will be greatly minimised and unrestricted travel will be possible." $\left(21^{\text {st }}\right.$ October 1942), sentiments he restated in 1948. The EU's origins lie in the desire for a European Economic Community (EEC) which was established in 1957 through the Treaty of Rome and was originally signed by six countries (France, West Germany, Italy, Belgium, the Netherlands, and Luxembourg) (Fligstein \& Stone Sweet, 2001). The domestic and international strategies undertaken to exclude the UK at that point are well documented (Van Herk, Poortinga \& Verhallen, 2004).

It was in 1973 that the UK joined the EU but with scepticism regarding the extent of political integration required for economic integration (Anderson \& Reichert, 1995). Generally referred to as the European Community until 1993, the EU was established in 1993 through the Treaty on European Union, more commonly known as the Maastricht Treaty (Grieco, 1995). The Maastricht Treaty "introduces the concept of European citizenship, reinforces the powers of the European Parliament and launches economic and monetary union" (Treaty on European Union, 1992). To explain, the concept of European citizenship includes the free movement to, and residence in, any EU country for all EU citizens. On economic union, the EU's policies and laws are designed for an internal market that enables the free movement of people, goods, service and capital as well as common policies on

\footnotetext{
${ }^{2}$ Current EU member states are: Austria, Belguim, Bulgaria, Croatia, Cyprus, Czech Republic, Denmark, Estonia, Finland, France, Germany, Greece, Hungary, Ireland, Italy, Latvia, Lithuania, Luxembourg, Malta, Netherlands, Poland, Portugal, Romania, Slovakia, Slovenia, Spain, Sweden, United Kingdom.
} 
agriculture (Moyer \& Josling, 2002), fisheries (Holden \& Garrod, 1996) and regional development (Ansell, 2000). It is estimated that the EU contributes substantially towards a country's Gross Domestic Product (Lejour \& De Mooij, 2001; Knox, Agnew \& McCarthy, 2014). On monetary union, since 2002 nineteen EU member states have adopted the Euro currency - a monetary union which the UK rejected (De Grauwe, 2006).

Characterised as a non-elected 'super power' (Bailes, 2008), the EU also has roles in peace (winning the Nobel Peace Prize in 2012), defence (e.g. EU's Foreign and Security Policy combines defence with diplomatic roles in the G8, G20, United Nations (McCormick, 2014)), and justice and home affairs (through member states adhering to EU legislation). The issue of border control varies across the EU not least because of the Schengen Treaty (which abolished passport controls for Schengen states) (Lutz, 2002).

In 2004, the new European Constitution streamlined existing treaties to improve decision making procedures, particularly political decisions meaning the EU became integral to the public policies of most member states (Nugent, 2010). The most recent amendment is the 2009 Treaty of Lisbon (Feldstein, 2012) which is viewed as a route to tightening EU decision making and intergovernmentalism (Puetter, 2012) and, by some, as constraining the sovereignty of member states.

In terms of citizens and their view of the EU, in 1973 the EU began a 'Eurobarometer' ${ }^{3}$ to test the mood of citizens towards the EU by assessing twice yearly the views of approximately 1000 citizens from each EU country in face-to-face interviews. Most recently assessed the month before the Brexit referendum (i.e. 21-31st May 2016 and published in July 2016), results show that $48 \%$ of respondents thought that immigration was one of the most important issues facing the EU - for every member state, except Portugal. The level of optimism in citizens about the future of the EU had dropped since the previous report by $3 \%$ to $50 \%$ to the lowest level since 2013. In the July 2016 Eurobarometer, respondents from the UK were placed $25^{\text {th }}$ (out of 28 member states) in terms of their optimism for the future of the EU. Furthermore, UK respondents were placed: $23^{\text {rd }}$ most optimistic on the impact of the economic crisis on the job market; $27^{\text {th }}$ in support for whether public money should stimulate private sector investment at the EU level; $28^{\text {th }}$ in support for a digital single market in the EU; $28^{\text {th }}$ in support for a common energy policy among member states; $28^{\text {th }}$ in support for the free movement of citizens; $28^{\text {th }}$ in support for European economic monetary union with a single currency; $19^{\text {th }}$ in support for the EU voice counting in the world.

\footnotetext{
${ }^{3}$ Standard Eurobarometer 86 (2016) Public opinion in the European Union, First Results. Autumn.
} 
In the UK, these issues come into sharp focus inside the Conservative political party (the party in government which called the referendum) which has suffered from decades of tension over the UK's closeness to the EU. The surge of a Eurosceptic political party, United Kingdom Independence Party (UKIP), intensified the pressure on Conservative Members of Parliament (MPs) who pushed the Conservative Prime Minister to promise a referendum on Britain's membership of the EU. The tension is stark when comparing the UK's three largest political parties in terms of their MPs' support for Leave/Remain: governing party - 138 MPs declared they would vote Leave against 185 MPs for Remain (Conservative Party 138/185); the official opposition to the governing party - strong Remain vote (Labour Party, 10/218); the governing party in Scotland - unanimous Remain vote (Scottish National Party, 0/54)

The Leave outcome was described as "Britain's independence day" (Nigel Farage, Leader: UKIP, UK) and received international congratulations: "Victory for Freedom!" (Marine Le Pen, Leader: National Front, France) and "a great thing ... a fantastic thing" (Donald Trump, Presidential candidate, USA). However, it was also met with dismay: "deeply regrets the UK's decision" (Angela Merkel, Chancellor, Germany) and "painful choice. And I regret it deeply," (Francois Hollande, President, France). It brought the immediate resignation of the Conservative Party Leader (the Prime Minister) and, soon after, an overwhelming vote of no confidence in the Labour Party Leader (172 to 40 MPs) - both leaders being on the losing Remain side. Within days, the value of UK's currency had hit a 31-year low $^{5}$, businesses were nervous about major UK investment decisions ${ }^{6}$, the UK's credit rating was downgraded", and the outcome had "wiped out over two trillion dollars of value" from world market ${ }^{8}$.

From this brief introduction, it is clear that the decision on whether the UK should stay in the EU was multi-faceted and complex. We now introduce political debates and show the suitability of causal mapping to analyse those.

\section{Soft OR to analyse debates}

Political debates can be "a powerful stimulus for speech communication" (Work and Boileau, 1985) but their format is heavily contested (e.g. their structure, number of debaters) and they are criticised in hindering the natural rhythm of dialogue (e.g. being media events involving staging, camera management, formats suitable for broadcasting, and selection of questioner) (see e.g. Cho and Choy,

\footnotetext{
${ }^{4}$ BBC, "EU vote: Where the cabinet and other MPs stand", $22^{\text {nd }}$ June 2016.

${ }^{5}$ The Guardian, "Sterling hits new 31-year low against the dollar", $6{ }^{\text {th }}$ July 2016.

${ }^{6}$ The Telegraph, "Small businesses face funding gap after Brexit vote", $28^{\text {th }}$ June 2016.

7 BBC, "Ratings agencies downgrade UK credit rating after Brexit vote", $27^{\text {th }}$ June 2016.

${ }^{8}$ The Guardian, “Brexit panic wipes \$2 trillion off world markets - as it happened", $25^{\text {th }}$ June 2016.
} 
2011; Schroeder, 2008). Debates can involve one debater being asked questions to which they respond perhaps including audience questions (much like an individual interview), or can involve more people either answering questions or having a multi-lateral discussion (much like a group workshop discussion). Either way, the aim of the debater is twofold: to support and promote the strengths of their own position; and to challenge the opposing view and undermine that argument (GrebelskyLichtman, 2015). Debates encourage viewers' engagement with politics (Gottfried, Hardy, Holbert, Winneg \& Jamieson, 2016), increase viewers' knowledge (Benoit, Hansen \& Verser, 2003) and may influence undecided voters, change voters' positions, and encourage non-voters to vote (GrebelskyLichtman, 2015). However, they may not be the best means of communicating information in being personality-driven and encouraging conflict (Schroeder 1998) and, conceivably, the aim of a debater is to persuade viewers (Carlin 2000) with plausible (not necessarily correct) information.

Televised debates allow debaters to promote the public face of their campaign and researchers have used televised debates as secondary research data (e.g. Grebelsky-Lichtman, 2015). On the analyses done, investigations have analysed the content of televised debates (Benoit and Sheafer, 2006), the social interactions between debaters (Vinciarelli et al, 2009), and tweets from viewers (Vergeer and Franses, 2016). We focus on the content of the argument. On this, Johnson (2009, pp19-23) discusses how debates contain chains of argument - the most straightforward being a "simple model" (a piece of evidence supporting a claim), but increasing in complexity from the "chain model" (a chain of evidence supporting a claim), "cluster model" (a variety of evidence supporting a claim), to a "complex model" (which combines chain and cluster models). However, such chains do not explain the consistency of the message as all these models could present consistent or inconsistent messages.

Given our OR focus and audience, we selected our analytical techniques from the suite of OR tools that are available to analyse individual interviews and group workshops and these originate from soft OR. These are a class of techniques to structure the complexity of qualitative data to better understand its content (Rosenhead \& Mingers, 2001), an example being causal mapping (designed to explore different views of a situation) (Ackermann et al, 2014). The tools from soft OR are well placed to help understand the differences in the arguments offered for and against Brexit for the following reasons: First, the topic is pluralistic (Jackson \& Keys, 1984) with a variety of debaters presenting differing perspectives on issues (Jackson, 2006; Keys, 2006) - even within the same campaign 'side'. Also, these tools can manage the complexity associated with organising qualitative arguments, taking a holistic approach to mapping issues by representing the interrelationships of the opinions (Shaw, 2003). Soft OR tools record the argument in a model that captures key points and can show how issues inter-relate (Ackermann et al, 1997) and, contrary to debates, aim to achieve agreement or 
accommodation (Checkland, 1985) about issues through establishing a shared understanding (Ackermann, Howick, Quigley, Walls \& Houghton, 2014). In building a model, the personality of the speaker is neutralised meaning that the model records what was said, not the manner in which it was said.

In terms of the soft OR tool we chose to analyse the debates, the paper draws on causal mapping (Ackermann et al, 2014) which has foundations in Personal Construct Theory (Kelly, 1955) and is a widely used technique (Ranyard, Fildes \& Tun-I, 2015) that aims to uncover important themes and causal relations in qualitative data. Causal mapping has been designed to analyse the sorts of data available here i.e. individual interviews through cognitive mapping technique (Eden, 1988) and group discussion through group mapping (Shaw, 2003). It has also been used to analyse secondary data, specifically private documents (Eden \& Ackermann, 2004; Williams et al, 2003) but such research has uncovered difficulties of coding causal structures when analysing secondary data because of the lack of interaction with experts. However, causal mapping is suitable if such difficulties can be resolved as it fits well with Johnson's (2009) representations of simple to complex chains of arguments being presented in debates. To explore such chains, analysing a causal map can be done in several ways including by mathematical analysis of the concepts and links which represent the argument (Eden, 2004), the nature of the argument built (Shaw, 2003), or the substantive content of the argument (Ackermann, Howick, Quigley, Walls, \& Houghton, 2014).

In this paper we apply causal mapping across nine debates to model the verbal arguments provided from the Leave and Remain campaigns for why voters should give them their vote. We examine how such arguments changed over time - a new aspect of longitudinal analysis to which Soft OR methods have not before been applied. Other non-Soft OR forms of causal mapping have been applied to longitudinal data, for example, Barr et al (1992) analysed the contents of 50 annual reports to shareholders that were issued by two companies over a 25 -year period. Their methods of analysis were designed to uncover learning by top management, specifically, through searching documentation for significant changes in the mental model over time - such as changes in causal sign between established relationships. In contrast, our aim is to understand the prominent narratives of what was said through the debates and so we opt for more of a thematic analysis. It is important to note a philosophical difference between our application of causal mapping and Eden's application. Eden aligns with Kelly (1955) who "focuses on the relation of influence that occurs during the act of communication" (Rutkowski \& Smits, 2001, p69) and so take a "constructivist approach" (ibid, p69) to embrace the modelling process as a negotiation of shared meanings by participants. This position is not appropriate for the modelling of our secondary data. Debates, in our sense, are objective data - 
the debate exists as an artefact of what was said and can be viewed. Voters who watch the debate may seek to assess the legitimacy of an objective reality being proposed, and are constructivists in that regard. However, our analysis does not explore voters' interpretations. Instead, to analyse the debate as an objective artefact, we need to be closer to a realist ontology. In our study causal mapping requires interpretation of the objective data by the modeller and so we "accept epistemic relativity (that knowledge is always local and historical)" (Mingers, Mutch \& Willcocks, 2013, p795). Furthermore, we reject that this is a single reality as different modellers could prioritise different content i.e. "not [accept] judgmental relativity (that all viewpoints must be equally valid)" (ibid, p795). These are two conditions for Critical Realism (ibid). The methodological aim of this paper is to understand the sorts of analyses that are possible in this case, and so we prefer to explain the analysis first before we explore our philosophical conclusions (Aim 3). Thus, we address Aim 3 in the Discussion section.

To address our first (methodological) aim we apply causal mapping technique to a new sort of data (longitudinal and secondary data), in order to make sense of the complexity of the situation (thereby achieving our fourth, modelling complexity, aim). By applying a widely used technique to publicly accessible data, others can replicate our analysis (our second aim). Our third (philosophical) aim is pursued in the Discussion section. We now describe the selection of data and how causal mapping was applied.

\section{Methodology}

\section{Selection of data}

Debates were selected using four criteria. First, to ensure availability to mass voters, each debate needed to have been broadcasted through free-to-air UK Television i.e. channels BBC1, ITV, Channel 4, Channel 5 and Sky News. Second, the debates had to focus on key people from either the Leave or Remain campaign to ensure the argument presented was legitimised by the credibility of the speaker. Here we recognised the need to look beyond only the two official campaigns as appointed by the Electoral Commission (Vote Leave Ltd, and The In Campaign Ltd). For example, Nigel Farage is included as a key person in the Leave campaign as leader of UKIP and leader of the Grassroots Out campaign. Third, to ensure only debates were selected, debaters had to be questioned by a moderator and/or members of the public. Fourth, to ensure focus on Brexit, the programme needed to be wholly dedicated to the EU referendum therefore a single interview on a news programme would not qualify. There was no requirement that both campaigns be present nor that more than one person be questioned at any given time. These criteria ensured we were able to focus on the more substantial 
debates having the widest reach that put across key arguments from those shaping the public discourse. Table 1 summarises the selected debates.

\begin{tabular}{|c|c|c|c|}
\hline $\begin{array}{l}\text { Programme } \\
\text { name }\end{array}$ & $\begin{array}{l}\text { Details (Length, } \\
\text { date/time of airing, } \\
\text { viewing figures, } \\
\text { channel) }\end{array}$ & Format and participants & $\begin{array}{l}\# \text { concepts and debate } \\
\text { themes in the debate map }\end{array}$ \\
\hline $\begin{array}{l}\text { 1. How should I } \\
\text { vote: The EU } \\
\text { debate }\end{array}$ & $\begin{array}{l}60 \text { mins on } 26 \text { th } \\
\text { May at } 8 p m \text { on } \\
\text { BBC1 }\end{array}$ & $\begin{array}{l}\text { Group Debate: } \\
\text { Leave (Liam Fox, Diane } \\
\text { James) } \\
\text { Remain (Alex Salmond, Alan } \\
\text { Johnson) }\end{array}$ & 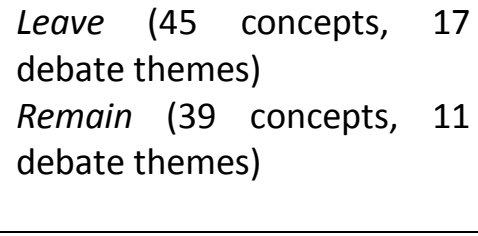 \\
\hline $\begin{array}{l}\text { 2. EU: In or Out? } \\
\text { David Cameron }\end{array}$ & $\begin{array}{l}60 \text { mins on } 2 \text { nd } \\
\text { June at } 8 p m \text { on } \\
\text { Sky News }\end{array}$ & $\begin{array}{l}\text { Individual Debate: Remain } \\
\text { (David Cameron) }\end{array}$ & $\begin{array}{l}\text { Remain (52 concepts, } 18 \\
\text { debate themes) }\end{array}$ \\
\hline $\begin{array}{l}\text { 3. EU: In or Out? } \\
\text { Michael Gove }\end{array}$ & $\begin{array}{l}60 \text { mins on 3rd } \\
\text { June at } 8 p m \text { on } \\
\text { Sky News }\end{array}$ & $\begin{array}{l}\text { Individual Debate: } \\
\text { Leave (Michael Gove) }\end{array}$ & $\begin{array}{l}\text { Leave (66 concepts, } 19 \\
\text { debate themes) }\end{array}$ \\
\hline $\begin{array}{l}4 . \quad \text { New: } \\
\text { Cameron and } \\
\text { Farage Live: The } \\
\text { EU Referendum }\end{array}$ & $\begin{array}{l}60 \text { mins on } 7 \text { th } \\
\text { June at } 9 \mathrm{pm} \\
\text { (3.54m viewers) } \\
\text { on ITV1 }\end{array}$ & $\begin{array}{l}2 \text { Individual Debates: Leave } \\
\text { (Nigel Farage) } \\
\text { Remain (David Cameron) }\end{array}$ & $\begin{array}{l}\text { Leave ( } 25 \text { concepts, } 8 \text { debate } \\
\text { themes) } \\
\text { Remain ( } 43 \text { concepts, } 16 \\
\text { debate themes) }\end{array}$ \\
\hline $\begin{array}{l}\text { 5. New: The ITV } \\
\text { Referendum } \\
\text { Debate }\end{array}$ & $\begin{array}{l}120 \text { mins on 9th } \\
\text { June at } 8 \mathrm{pm} \\
\text { ( } 2.71 \mathrm{~m} \text { viewers) } \\
\text { on ITV1 }\end{array}$ & $\begin{array}{l}\text { Group Debate: Leave (Boris } \\
\text { Johnson, Andrea Leadsom, } \\
\text { Gisela Stuart) } \\
\text { Remain (Angela Eagle, } \\
\text { Amber Rudd, Nicola } \\
\text { Sturgeon) }\end{array}$ & $\begin{array}{l}\text { Leave (74 concepts, } 34 \\
\text { debate themes) } \\
\text { Remain ( } 74 \text { concepts, } 23 \\
\text { debate themes) }\end{array}$ \\
\hline $\begin{array}{l}\text { 6. EU Special: } \\
\text { The Case for } \\
\text { Leave }\end{array}$ & $\begin{array}{l}45 \text { mins on 15th } \\
\text { June at } 6.45 \mathrm{pm} \\
\text { on } B B C 1\end{array}$ & $\begin{array}{l}\text { Individual Debate: Leave } \\
\text { (Michael Gove) }\end{array}$ & $\begin{array}{l}\text { Leave (62 concepts, } 29 \\
\text { debate themes) }\end{array}$ \\
\hline $\begin{array}{l}\text { 7. EU Special: } \\
\text { The Case for } \\
\text { Remain }\end{array}$ & $\begin{array}{l}45 \text { mins on } 19 \text { th } \\
\text { June at } 6.45 p m \\
\text { on } B B C 1\end{array}$ & $\begin{array}{l}\text { Individual Debate: Remain } \\
\text { (David Cameron) }\end{array}$ & $\begin{array}{l}\text { Remain (74 concepts, } 23 \\
\text { debate themes) }\end{array}$ \\
\hline $\begin{array}{l}\text { 8. EU: In or Out? } \\
\text { Jeremy Corbyn }\end{array}$ & $\begin{array}{l}60 \text { mins on 20th } \\
\text { June at } 8 p m \text { on } \\
\text { Sky News }\end{array}$ & $\begin{array}{l}\text { Individual Debate: } \\
\text { Remain (Jeremy Corbyn) }\end{array}$ & $\begin{array}{l}\text { Remain ( } 49 \text { concepts, } 23 \\
\text { debate themes) }\end{array}$ \\
\hline $\begin{array}{l}9 . \quad \text { EU } \\
\text { Referendum: } \\
\text { The Great } \\
\text { Debate }\end{array}$ & 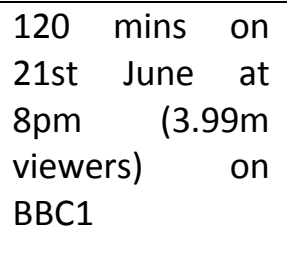 & $\begin{array}{l}\text { Group Debate: Leave (Boris } \\
\text { Johnson, Andrea Leadsom, } \\
\text { Gisela Stuart) } \\
\text { Remain (Ruth Davidson, } \\
\text { Sadiq Kahn, Frances } \\
\text { O'Grady) }\end{array}$ & $\begin{array}{l}\text { Leave (66 concepts, } 32 \\
\text { debate themes) } \\
\text { Remain ( } 83 \text { concepts, } 21 \\
\text { debate themes) }\end{array}$ \\
\hline
\end{tabular}

Table 1 - Details of the Brexit debates selected for analysis 


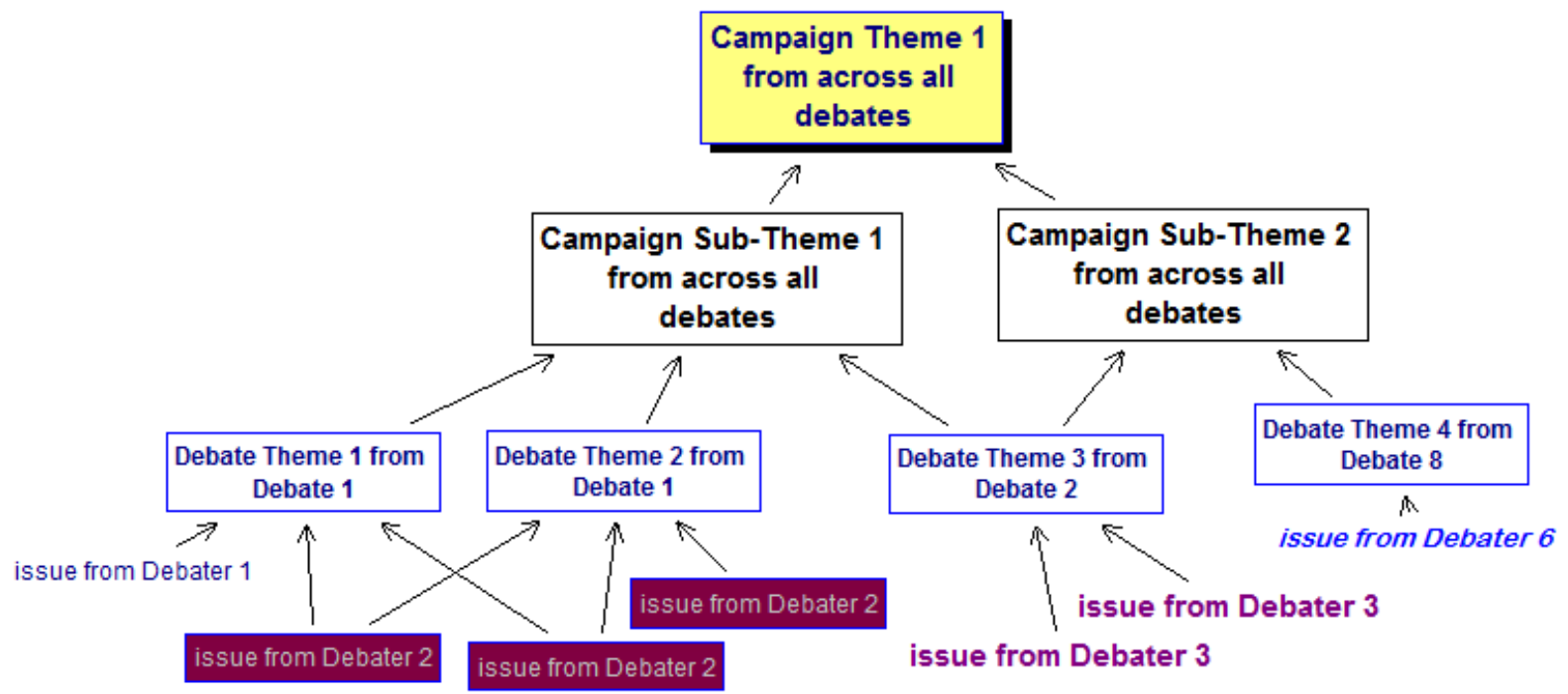

Figure 1 -Structure of a Campaign Theme causal map

\section{Analysing through causal mapping}

The first activity was for the research team to understand the context to the referendum and select the debates using the four criteria. Then, each selected debate was downloaded and listened to several times and the issues said by debaters were identified. The building of causal maps followed Eden (1988) as, for example, each time a new issue was mentioned it was typed into a causal map computer model. Separate issues were added as new concepts in the map (see Figure 1 which shows the relationship between issues, debate themes, campaign sub-themes and campaign themes). Thus, the process of identifying the issues only emerged from the audio data through a process akin to open coding of Grounded Theory (Strauss and Corbin, 1998). Within debates, when related issues were mentioned, the concepts were grouped together into content-related clusters to form themes - akin to axial coding in Grounded Theory. These clusters were given descriptive 'debate theme' titles. The causal relationship between concepts identified by the debater was coded as an arrow between those concepts in the map. Identifying relationships/arrows was done within and across debate themes. Where multiple debaters argued on the same theme these were recorded alongside each other. Dependability of the research process was enhanced through using a rigorous procedure that involved one researcher building the initial maps from video data, creating as robust a representation as possible using an appropriate procedure. Then a second researcher spent (on average) 1 hour per map to independently review the map, deconstruct the argument in detail, and identify potential recodings to further refine the representation. Then, both researchers worked together to discuss the initial coding and the revised coding to thoroughly check the concepts, links and themes - a process that took over 2 hours per map and sought to build confirmability through the audit trail contained in the maps. About 2 months after this, once the analytical methods had been developed, all the debates were re-watched along with the causal maps to explore whether those maps were a legitimate coding 
of the debates. In each case we identified minor amendments which would further refine the maps by adding or amending concepts that fed into existing debate themes. As these were minor amendments, not involving the development of new debate themes, we accepted the causal maps as a legitimate coding of the debates. The validity of this process was enhanced by treating the debates as objective data meaning the concepts were faithful representations of what was said and by peer scrutiny of the maps.

We analysed the mapped data in terms of its breadth which indicated the variety of themes within an argument. For a voter, breadth may appear like a scattergun debate style which raises issues that are not related, potentially chaotic - or as a coherent, broad-based argument. We also analysed the depth of argument in the causal maps (i.e. the proliferation of detail supporting themes). This was done by examining the number of concepts making up the themes. Lastly, we explored how the detail of campaign themes changed over four weeks leading up to the referendum by analysing for consistency over that time period. This research method had 6 activities (see Figure 2).

Stage 1 analysed the contributions made by each campaign within each debate. As we were analysing the content of the Leave and Remain campaigns and how this changed over time, we built one map per campaign per debate -13 debate maps in all (6 Leave and 7 Remain). To indicate the size of the debate maps, on average, they had 57.8 concepts and 83.3 links. By the end of modelling a debate, a campaign had several linked themes representing the argument being promoted to voters. To compare debate maps, we produced descriptive statistics on the number of concepts, links and themes covered to see if there were substantial differences between campaigns, and between debaters who debated on their own ('individual debaters') and those who debated as a group ('group debaters'). 


\section{Apply criteria to select debates}

Identified 9 debates

\section{Map the debates}

Mapped 13 debate maps (6 Leave $\& 7$ Remain maps across the 9 debates) involving 10.5 hours of debate

Stage 1 analysis: Develop and analyse debate themes

Analysed: \# concepts, \# links, \# debate themes, individual and group performance

\section{Stage 2 analysis: Develop and analyse campaign themes}

Analysed: \# campaign themes, \# debate themes in campaign themes, focus on core messages (or opposition's messages), individual and group performance

Stage 3 analysis: Develop and analyse campaign sub-themes Analysed: breadth \& consistency of campaign message over time

\section{Stage $\mathbf{4}$ analysis: Overall debate tactics \\ Analysed: Lessons from Stages 1-3 to abstract tactics}

Figure 2 - Research method activities

Stage 2 analysed across individual debates to understand the breadth and depth of campaign arguments for these debates. To accomplish this, we developed new methods of analysing causal maps from different points in time i.e. longitudinal data. Specifically, the 'debate theme' titles from Stage 1 were extracted from each debate map and re-themed across all debates from each side to create a smaller number of 'campaign themes' i.e. themes that were covered by a campaign (see Figure 1). This allowed us to track, for example, how campaign themes were constructed across different debates, how debate themes were picked up and dropped across the 9 debates, and how consistent themes established a bedrock on which the campaigns stood. To accomplish this, we had to re-classify 139 debate themes from Leave and 135 debate themes from Remain into (what emerged as) 15 campaign themes for Leave and 20 campaign themes for Remain. To ensure each debate theme was consistent with the others in the same campaign theme, each debate theme was validated by checking its similarity using the Stage 1 maps. We were normally able to code debate themes into a single campaign theme as their content was dominant towards one campaign theme. However, the concepts that made up debate themes were broad based and included references to other campaign 
themes which were not their dominant focus e.g. some concepts within the jobs campaign theme included information about the impact of immigration campaign theme - but immigration was not their core focus - and vice versa. A small number of debate themes fell evenly on the boundary of two campaign themes and, from the Stage 1 concepts, it was impossible to identify the dominant campaign theme so they were double-coded into both campaign themes e.g. in Figure 3 the debate theme [314] Immigration lowers standards of living for ordinary people was coded in two campaign themes ([802] Impact of immigration, [1070] Changes in quality of life). Please note, in Figures 3 and 4, the number for each concept is a unique reference number that is allocated by the software. This reference number is included in the text in square brackets when concepts in Figure 3 (and Figure 4) are referred to. Also, text in italics are quotes from the maps.

Campaign themes were initially developed by one researcher who focused on establishing credible themes. The procedure for doing so was replicated by a second researcher who coded the data to establish their own themes. The two sets of themes were then compared and a single set of campaign themes were agreed after considerable discussion - a process that took over 4 hours per campaign. As this process did not allocate debate themes to pre-identified campaign themes, the different campaign themes developed by the coders meant we could not assess inter-coder reliability. We produced descriptive statistics to compare the campaign themes from across each side of the debate.

Stage 3 conducted longitudinal analyses to understand how the Leave and Remain campaigns built breadth and consistency into their arguments across debates. We did not follow Johnson (2009) in analysing chains of argument as we were more interested in consistency than chains. Here, consistency is a measure of the repetition of campaign sub-themes in a campaign theme and was investigated through the extent to which campaigns formed a more substantial argument by synthesising different debate themes from across debates. Within campaign themes, we clustered each debate theme with other similar debate themes thereby creating 'campaign sub-themes' which described different aspects of a campaign theme (see Figure 1). We compared campaign sub-themes using descriptive statistics and graphically. For the graphic approach (see Figures $5 \& 6$ ), we analysed breadth (number of campaign sub-themes) and consistency. A consistency score for each campaign sub-theme was calculated by summing the square of how many debate themes made up the campaign sub-themes within a campaign theme. By squaring the number of debate themes, we aimed to accentuate (quantitatively) the impact of repeated focus on campaign sub-themes to symbolise the greater consistency added by every additional debate theme. Thus, a higher consistency score signals a more repeated campaign sub-theme. If a campaign theme was made up of one campaign sub-theme which was made up of 3 debate themes, then the consistency score would be $9\left(3^{2}\right)$. And, if a campaign 
theme was made up of 5 campaign sub-themes - one campaign sub-theme made up by 4 debate themes and four campaign sub-themes made up by 1 debate theme - then the consistency score would be $20\left(4^{2}+1^{2}+1^{2}+1^{2}+1^{2}\right)$. Below, we use 20 as a threshold because it accentuates a difference between the campaigns.

\begin{tabular}{|c|c|c|c|c|}
\hline $\begin{array}{l}\text { Campaign } \\
\text { theme } \\
\text { provides } \\
\ldots\end{array}$ & $\begin{array}{l}\text { Type of campaign } \\
\text { theme }\end{array}$ & $\begin{array}{l}\text { How to identify campaign theme } \\
\text { using campaign sub-themes and } \\
\text { debate themes }\end{array}$ & $\begin{array}{l}\text { \% of } \\
\text { Leave } \\
\text { campaig } \\
n \text { themes } \\
\text { (out of } 15 \\
\text { campaig } \\
n \\
\text { themes) }\end{array}$ & $\begin{array}{l}\% \text { of } \\
\text { Remain } \\
\text { campaig } \\
n \text { themes } \\
\text { (out of } 20 \\
\text { campaig } \\
n \\
\text { themes) }\end{array}$ \\
\hline \multirow{4}{*}{$\begin{array}{l}\text { cono } \\
\text { consistent } \\
\text { message } \\
\text { across } \\
\text { debates. }\end{array}$} & 1. Orphan. & $\begin{array}{l}\text { A campaign theme made up of a } \\
\text { campaign sub-theme which has up } \\
\text { to } 2 \text { debate themes. }\end{array}$ & $13.3 \%(2)$ & $\begin{array}{l}15.0 \%(3 \\
\text { candidat } \\
\text { e } \\
\text { themes) }\end{array}$ \\
\hline & $\begin{array}{l}\text { 2. Starts but then } \\
\text { fizzles out. }\end{array}$ & $\begin{array}{l}\text { A campaign theme made up of } \\
\text { campaign sub-themes which has up } \\
\text { to } 2 \text { debate themes in the first one } \\
\text { or two debates. No debate themes in } \\
\text { the remainder of the debates. }\end{array}$ & $6.7 \%(1)$ & $5.0 \%(1)$ \\
\hline & $\begin{array}{l}\text { 3. Didn't realise it was } \\
\text { an issue, then had to } \\
\text { respond. }\end{array}$ & $\begin{array}{l}\text { A campaign theme made up of } \\
\text { campaign sub-themes which have } \\
\text { no debate themes in the first half of } \\
\text { debates. More than one debate } \\
\text { theme in the second half of the } \\
\text { debates. }\end{array}$ & $13.3 \%(2)$ & $10.0 \%(2)$ \\
\hline & $\begin{array}{l}\text { 4. Multiple campaign } \\
\text { sub-themes with no } \\
\text { consistent message } \\
\text { running through the } \\
\text { debates. }\end{array}$ & $\begin{array}{l}\text { A campaign theme made up of } \\
\text { multiple campaign sub-themes } \\
\text { which have no common debate } \\
\text { themes across debates. May include } \\
\text { missed debates and could have } \\
\text { many campaign sub-themes. }\end{array}$ & $0.0 \%(0)$ & $35.0 \%(7)$ \\
\hline $\begin{array}{l}\text {...a } \\
\text { somewha } \\
\mathrm{t} \\
\text { consistent } \\
\text { message } \\
\text { across } \\
\text { debates. }\end{array}$ & $\begin{array}{l}\text { 5. Single campaign } \\
\text { sub-themes running } \\
\text { through the debates } \\
\text { (with other debate } \\
\text { themes providing } \\
\text { support). }\end{array}$ & $\begin{array}{l}\text { A campaign theme made up of a } \\
\text { campaign sub-theme that contains } \\
\text { at least } 1 \text { debate theme from each } \\
\text { debate (with the exception of up to } \\
2 \text { debates). }\end{array}$ & $26.7 \%(4)$ & $25.0 \%(5)$ \\
\hline $\begin{array}{l}\text {... very } \\
\text { consistent } \\
\text { messages } \\
\text { across } \\
\text { debates. }\end{array}$ & $\begin{array}{l}\text { 6. Multiple campaign } \\
\text { sub-themes running } \\
\text { through the debates } \\
\text { (with other debate } \\
\text { themes providing } \\
\text { added support). }\end{array}$ & $\begin{array}{l}\text { A campaign theme made up of } \\
\text { multiple campaign sub-themes that } \\
\text { contain at least } 1 \text { debate theme from } \\
\text { each debate (with the exception of } \\
\text { up to } 2 \text { debates). }\end{array}$ & $40.0 \%(6)$ & $10.0 \%(2)$ \\
\hline
\end{tabular}

Table 2 - Coding framework and results for campaign themes 
We also analysed how campaign themes were built by a consistent combination of campaign subthemes. To do this, we classified the composition of campaign themes by campaign sub-themes to develop a new coding framework that exploited the longitudinal nature of the data (see Table 2). The coding framework identifies for each campaign theme whether it provides no consistent message across debates (Types 1-4), a somewhat consistent message (Type 5), or a very consistent message with a number of campaign sub-themes being prolific across most debates (Type 6).

In Stage 3 we established transferability of the research process by developing clear analytical approaches to apply to the data and these are evident in Figure 1 and Table 2. Also note, we analysed 6 debates for Leave, compared to Remain's 7 debates, which converted to less airtime for Leave (465 minutes) than Remain (525 minutes). Hence, to enable easy comparison we analysed some results in 'per minute' of debate or 'per debate'. Due to the small number of debates, only descriptive statistics are possible and these are presented to one decimal place so as not to suggest an inappropriate level of precision. Also, we do not provide standard deviations due to space restrictions and to aid readability.

In Stage 4 we identified tactics for how campaign themes were built. These tactics were identified by abstracting from the insights gained from Stages 1-3 - akin to the identification of selective codes in Grounded Theory (Strauss and Corbin, 1998). As such the tactics connect across all our analysis and form a way of unifying the analysis. As Stage 4 presents our unifying findings which are illustrated through examples of debate content, we present these first in order to provide narrative insights to the debates. throughout our description of Stages 1-3. This also serves to explain the tactics which are referred to below.

\section{Analysis of the debates}

In this section, first we explain some of the debate content through a brief overview of debate tactics as found in Stage 4. Then, we report on the descriptive analyses from Stages 1-3 to explore if there are differences between the campaigns.

\section{Overview of debate tactics}

The analysis identified 24 campaign themes across Leave and Remain sides of the debate. Of these 11 were shared by both sides, 4 were unique to Leave and 9 unique to Remain. These are shown in Table 3 where they are ordered according to the relative dominance of the theme across the debates (here, dominance is assessed by counting the number of debate themes which make up each campaign theme, shown in brackets). 
Space prohibits a detailed discussion of each campaign theme so we focus on explaining five tactics for how these campaign themes were built across debates. To briefly explain these tactics, we focus on campaign themes and explain the tactics employed by each side. First, we consider how the tactic of creating traction was established, then how diversion was used, and we identify a tactic of taking opposing positions on issues. Then, we consider the presence of consistent threads running across campaign themes, and present a tactic of tapping into emotion. Many of these tactics were only discovered because we analysed the data longitudinally which illuminated, for example, how traction was build and lost across debates, and how consistent threads were built across debates.

\begin{tabular}{|l|l|l|}
\hline $\begin{array}{l}\text { Shared campaign themes } \\
\text { (ordered by \# debate themes) }\end{array}$ & $\begin{array}{l}\text { Campaign themes unique to } \\
\text { Leave (ordered by \# debate } \\
\text { themes) }\end{array}$ & $\begin{array}{l}\text { Campaign themes unique to } \\
\text { Remain (ordered by \# debate } \\
\text { themes) }\end{array}$ \\
\hline $\begin{array}{l}\text { Impact of immigration } \\
\text { (consisting of } 37 \text { debate } \\
\text { themes) }\end{array}$ & $\begin{array}{l}\text { EU is failing the UK (consisting } \\
\text { of } 15 \text { debate themes) }\end{array}$ & $\begin{array}{l}\text { Economic impact of leaving } \\
\text { (consisting of 15 debate } \\
\text { themes) }\end{array}$ \\
\hline Trade deals (24) & $\begin{array}{l}\text { Our money sent to the EU } \\
\text { which we have no control over } \\
\text { (15) }\end{array}$ & $\begin{array}{l}\text { New deal / EU reform is good } \\
\text { for UK (12) }\end{array}$ \\
\hline Whose opinion to trust (22) & $\begin{array}{l}\text { UK is strong enough to be } \\
\text { successful (12) }\end{array}$ & The EU is not that bad (9) \\
\hline Impact on public services (19) & $\begin{array}{l}\text { Insignificance of the UK in EU } \\
\text { decisions (4) }\end{array}$ & Isolation of the UK (9) \\
\hline Changes in quality of life (14) & & $\begin{array}{l}\text { The big risk of leaving (8) } \\
\text { blamed on the EU are not its } \\
\text { fault (6) }\end{array}$ \\
\hline Impact on jobs (13) & & $\begin{array}{l}\text { Benefits of free movement (5) } \\
\text { likely if we leave (2) }\end{array}$ \\
\hline Law making (11) & $\begin{array}{l}\text { Leave do not have a plan if they } \\
\text { win (2) }\end{array}$ \\
\hline $\begin{array}{l}\text { Changes in security by leaving } \\
\text { (9) }\end{array}$ & & \\
\hline The UK's sovereignty (5) & & \\
\hline $\begin{array}{l}\text { Protection of workers' rights } \\
\text { (4) }\end{array}$ & & \\
\hline Impact on border control (2) & & \\
\hline
\end{tabular}

Table 3: Shared and unique campaign themes 


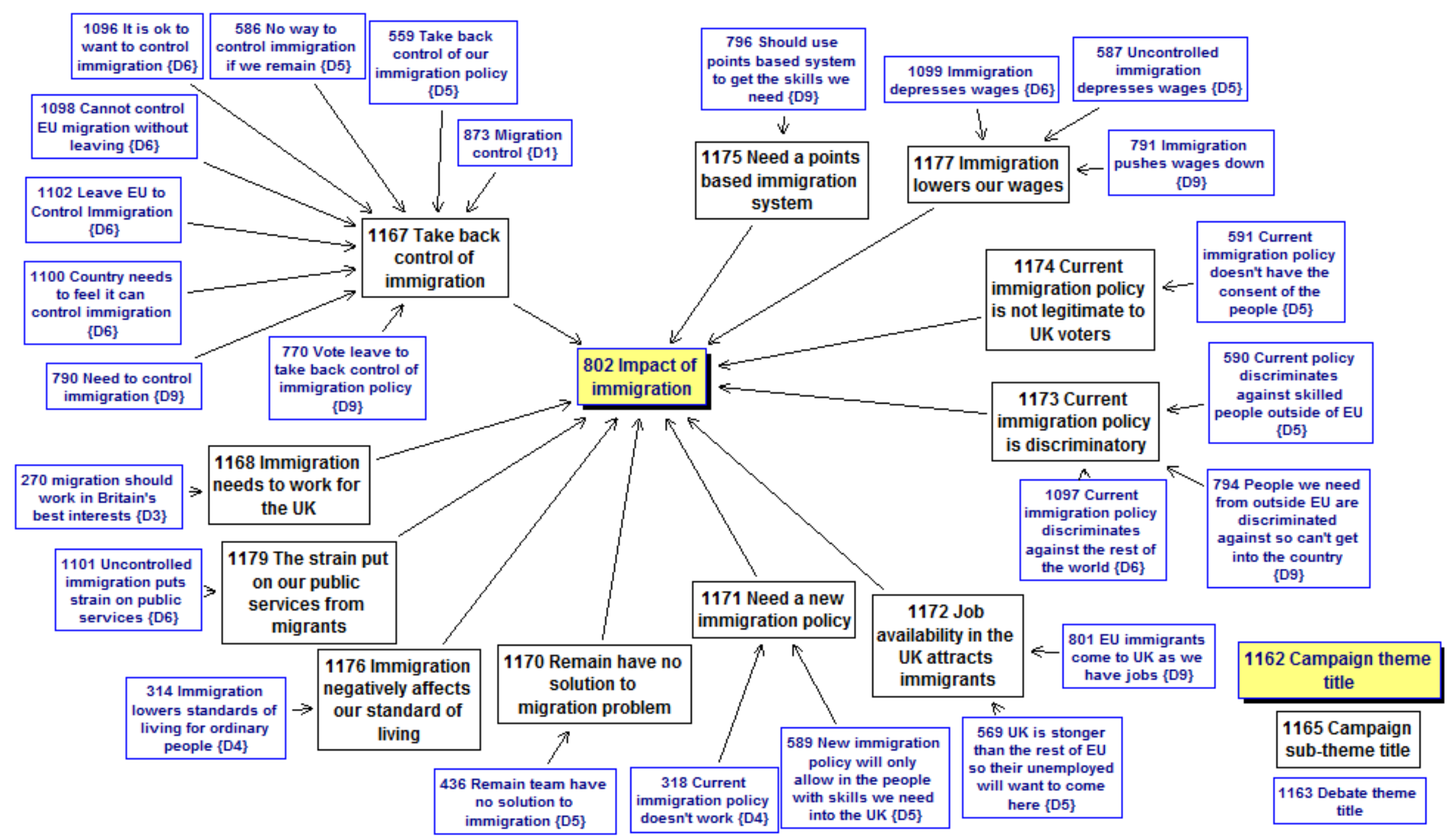

Figure 3: Extract from Leave map - Impact of immigration including campaign themes, campaign sub-themes and debate themes 


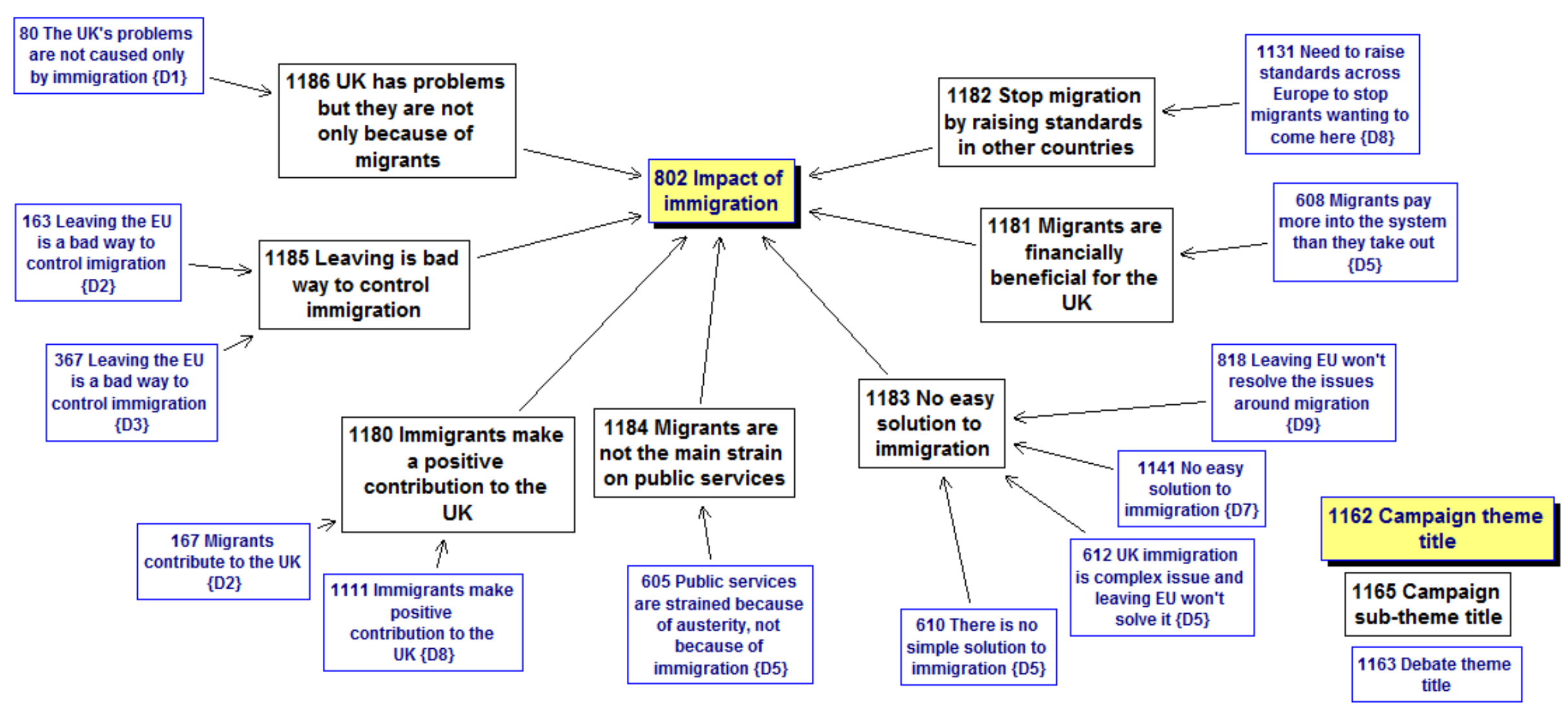

Figure 4: Extract from Remain map - Impact of immigration including campaign themes, campaign sub-themes and debate themes 
In Table 3 the most dominant campaign theme was Impact of immigration with 37 debate themes to which Leave contributed 25 debate themes (see Figure 3) while Remain contributed 12 (see Figure 4). Figure 3 shows an extract from the Leave map for [802] Impact of immigration showing the breadth of the campaign sub-themes and debate themes. Across debates, in particular Debates 5, 6 and 9, Leave established traction through a consistent and wide reaching message on immigration anchored in the campaign sub-theme [1167] Take back control of immigration (which appeared in four debates) and supported by 10 other campaign sub-themes. In the debate themes in Figure 3, the number in curly brackets is the debate number (i.e. ' $\{D 1\}$ ' is Debate 1 ) and, through this, we can see the timing of how the complexity of the campaign themes was built across debates e.g. [873] Migration control in Debate 1. However, [873] Migration control is not the full extent of Leave's commentary on immigration in Debate 1 as debaters also contributed concepts that mentioned the impact of immigration in the context of other campaign sub-themes, such as: Competition for UK jobs, reduction in UK living standards, pressure on services and housing, and the need to establish Stronger links with the Commonwealth countries rather than the EU. As those concepts were dominated by those other issues they feature elsewhere, especially in Debates 1, 3 and 4. In later debates, when migration had significant traction, Leave refocused on migration as the core issue rather than as a part of other themes.

Remain did not establish traction on immigration. As evident from Figure 4, Remain addressed immigration in the first three debates predominantly around 3 campaign sub-themes: UK has problems but they are not only because of migrants; Leaving is a bad way to control immigration, and; Immigrants make a positive contribution to the UK. However, these campaign sub-themes did not gain traction and were dropped in later debates to be replaced with: No easy solution to immigration. Some campaign sub-themes were trialled by debaters but failed to gain traction and so were not mentioned in subsequent debates e.g. Remain's argument of Migrants are not the main strain on public services; Immigrants are financially beneficial for the UK, and; Stop migration by raising standards across Europe.

Analysing the data longitudinally to identify how the focus on themes changes during the campaign, Table 4 uses Figure 3 and 4 to understand the changing focus on [802] Impact of immigration. Neither debate had an overwhelming initial focus on immigration with only 1 or 2 debate themes in the early debates - although (as mentioned above) Leave tended to talk about immigration in the context of other issues/themes. Remain put emphasis on immigration only in Debate 5 (establishing 4 debate themes) which enabled Leave to talk in a more concentrated way about immigration in Debate 5 and capitalise on their existing traction by establishing 8 debate themes. Leave then extended their focus 
on immigration in subsequent debates. To illustrate Leave's growing argument, Figure 3 and Table 4 show the comparative simplicity of how this issue was addressed in Debate 1 (in which only 1 debate theme was covered) and the increased breadth of argument created throughout the debates until Debate 9 (in which 6 debate themes were covered). There is also very little direct overlap in the debate themes from across debates, but a lot of complementary debate themes which reinforce messages from earlier debates, as well as the constant message to [1167] Take back control of immigration.

\begin{tabular}{|l|c|c|}
\hline $\begin{array}{l}\text { Debate } \\
\text { number }\end{array}$ & $\begin{array}{c}\text { Number of debate themes created by } \\
\text { Leave in each debate (from Figure 3) }\end{array}$ & $\begin{array}{c}\text { Number of debate themes created by } \\
\text { Remain in each debate (from Figure 4) }\end{array}$ \\
\hline 1 & 1 & 1 \\
\hline 2 & Not represented at debate & 2 \\
\hline 3 & 1 & Not represented at debate \\
\hline 4 & 2 & 1 \\
\hline 5 & 8 & Not represented at debate \\
\hline 6 & 7 & 1 \\
\hline 7 & Not represented at debate & 2 \\
\hline 8 & Not represented at debate & 1 \\
\hline 9 & 6 & \\
\hline
\end{tabular}

Table 4 - How debate themes built the complexity of campaign sub-themes across debates for [802] Impact of immigration

From Table 3, it is striking that the campaign theme Economic impact of leaving is unique to Remain. This appeared deliberate from Leave debaters who avoided any attempt at gaining traction on this and instead diverted the conversation away from the economy to campaign themes that aligned with the economy. For example, they diverted onto Trade deals where they argued that Global economies are more important and so the UK should Take back control of trade policy. They also diverted from economy onto campaign theme Changes in quality of life by arguing for the need to Focus on quality of life not GDP. And they diverted onto Our money sent to the EU which we have no control over, asserting that the EU costs $f 10 b n$ more per year than we get back, and that People spending our money don't have our priorities. They also used the current strength of the UK economy to suggest that the UK is strong enough to be successful. By diverting focus away from economy, Leave did not engage with one of Remain's core campaign themes thus preventing Remain from being able to fully debate the theme and present weaknesses in Leave's position.

When each side had equal traction it was often because they debated from opposite positions of the same campaign sub-themes. This was seen in the campaign theme Who to trust where Remain had 3 main campaign sub-themes: Leave are scaremongering; Expert opinion agrees with us, and; Fact based argument. Leave focused on the same campaign sub-themes but from the opposite viewpoint: Remain are scaremongering; Business and job creators want to leave, and; Experts can be wrong. This tactic may have originated from either side as an attempt to obfuscate the strength of the opposition's 
message. Opposing positions tactic are repeated in other dominant campaign themes, such as; Impact on jobs, Trade deals, Impact on public services and, Changes in quality of life.

Some issues were so pervasive that they formed their own consistent thread throughout a variety of campaign themes. As an example, across most the debates and most campaign themes, Leave had a consistent message about 'taking back control' - indeed, this was the slogan of their campaign. Of Leave's 139 debate themes, 51 were about reclaiming control covering themes such as Trade deals, where Outside the EU we can control our trade deals; Immigration, where the UK should $t=$ Take back control or our immigration policy, and; Law making, where voters were encouraged to vote Leave to take back control of law making. Remain had no similar example of consistent threads running through their arguments that spread through to so many debate themes.

Our last tactic was extensively used in all debates - the exploitation of voter emotion to encourage support for their side. Both Leave and Remain drove home the need to be concerned if the other side won the referendum and overtly pitched their argument to hit the emotions of individuals - less often geared towards a positive emotion. Many campaign themes in Table 3 are positioned emotively. Just two examples of debate themes from Leave's (Remain are using project fear to scare you into staying and leaving will unlock the potential of the British people) and from Remain (Leave are telling lies and leaving will damage the NHS through reduced taxation and spending) show their emotive nature. Importantly, this emotive tactic was consistently employed without reference to any facts to justify the hype - indeed voters were often told by Leave that The experts on the remain side are not credible or independent and Remain argued that Leave don't like experts because they don't support them. However, this tactic was not always employed by Remain. Initially they appeared to take a more educational approach to the initial debates by attempting to raise voters' knowledge about the EU and its merits - providing a more fact-based argument with evidence, for example the extent to which migrants contribute towards the economy.

We will revisit these tactics after we report on Stage 1-3.

\section{Stages 1-3 Analysis of maps}

To aid the readability of the analysis of maps we summarise the main findings in Table 5 and explain these in detail below.

\section{Leave}

Remain 


\begin{tabular}{|l|l|lr|}
\hline Stage 1 & $\begin{array}{l}\text { Covered a greater number of debate } \\
\text { themes in each debate and individual } \\
\text { debaters contributed more information } \\
\text { to each debate theme }\end{array}$ & $\begin{array}{l}\text { Contributed more information in the } \\
\text { debates and group debaters contributed } \\
\text { more information to each debate theme }\end{array}$ \\
\hline Stage 2 & $\begin{array}{l}\text { Focused more on core messages. Formed } \\
\text { campaign themes containing more } \\
\text { debate themes and more campaign sub- } \\
\text { themes. Individual and group debaters } \\
\text { covered greater proportion of campaign } \\
\text { themes. }\end{array}$ & $\begin{array}{l}\text { Identified a greater number of campaign } \\
\text { themes, and unique campaign themes. } \\
\text { Individual debaters covered more } \\
\text { campaign themes. }\end{array}$ \\
\hline Stage 3 & $\begin{array}{l}\text { Developed campaign themes } \\
\text { longitudinally with a stronger consistent } \\
\text { message }\end{array}$ & $\begin{array}{l}\text { Developed campaign } \\
\text { longitudinally with lower consistent } \\
\text { message }\end{array}$ \\
\hline $\begin{array}{l}\text { Stage } \\
\text { Overview } \\
\text { of debate } \\
\text { tactics }\end{array}$ & $\begin{array}{l}\text { Stronger traction but on a smaller } \\
\text { number of themes } \\
\text { Did not chase themes that were off } \\
\text { message } \\
\text { Took opposing positions to Remain } \\
\text { Stronger consistent threads }\end{array}$ & $\begin{array}{l}\text { Weaker traction but on a broader } \\
\text { number of themes } \\
\text { Chased Leave's themes } \\
\text { Took opposing positions to Leave } \\
\text { Weak consistent threads } \\
\text { Focused on emotive aspects of campaign } \\
\text { themes }\end{array}$ & themes on emotive aspects of campaign \\
\hline
\end{tabular}

Table 5-Overview of results

From Stage 1's debate maps, Remain debaters made more contributions than those from Leave. On average, the 6 Leave maps had 56.3 concepts and 78.2 links while the 7 Remain maps had 59.1 concepts and 87.7 links -meaning the Remain had more information in their maps although the maps are similarly interconnected (evident through similar proportions of links per concept). Other evidence comes from Remain's individual debaters - they contributed slightly more concepts (1.0 per minute), links (1.4 per minute), and proportion of links per concept (1.5 ratio) than Leave (0.9 concepts; 1.3 links; 1.4 ratio). Breaking this down further, similar results were found for Remain group debaters: slightly more concepts ( 0.7 per minute), links ( 1.0 per minute), and proportion of links per concept (ratio 1.5$)$ than Leave (0.6 concepts; 0.9 links; 1.4 ratio).

Results show that Leave contributed more concepts to their debate themes than Leave. Here, across individual debates, debate themes were made up of more concepts by Leave (average 3.5 concepts) than Remain (2.9). Across the three group debates, debate themes received more focus from Leave debaters (average 1.3 concepts per debate theme per debater) than Remain (0.9).

Results also show that Leave debaters covered a greater number of debate themes with their concepts than Remain debaters. Here, Leave debaters covered more debate themes in each debate (average 23.2) compared to Remain (19.3) - albeit Leave contributed a similar number of debate themes overall (139) to Remain (135) but did so in one fewer debate. Together, these findings suggest that the greater 
number of contributions from Remain were not adding substantially to what had already been said by their side.

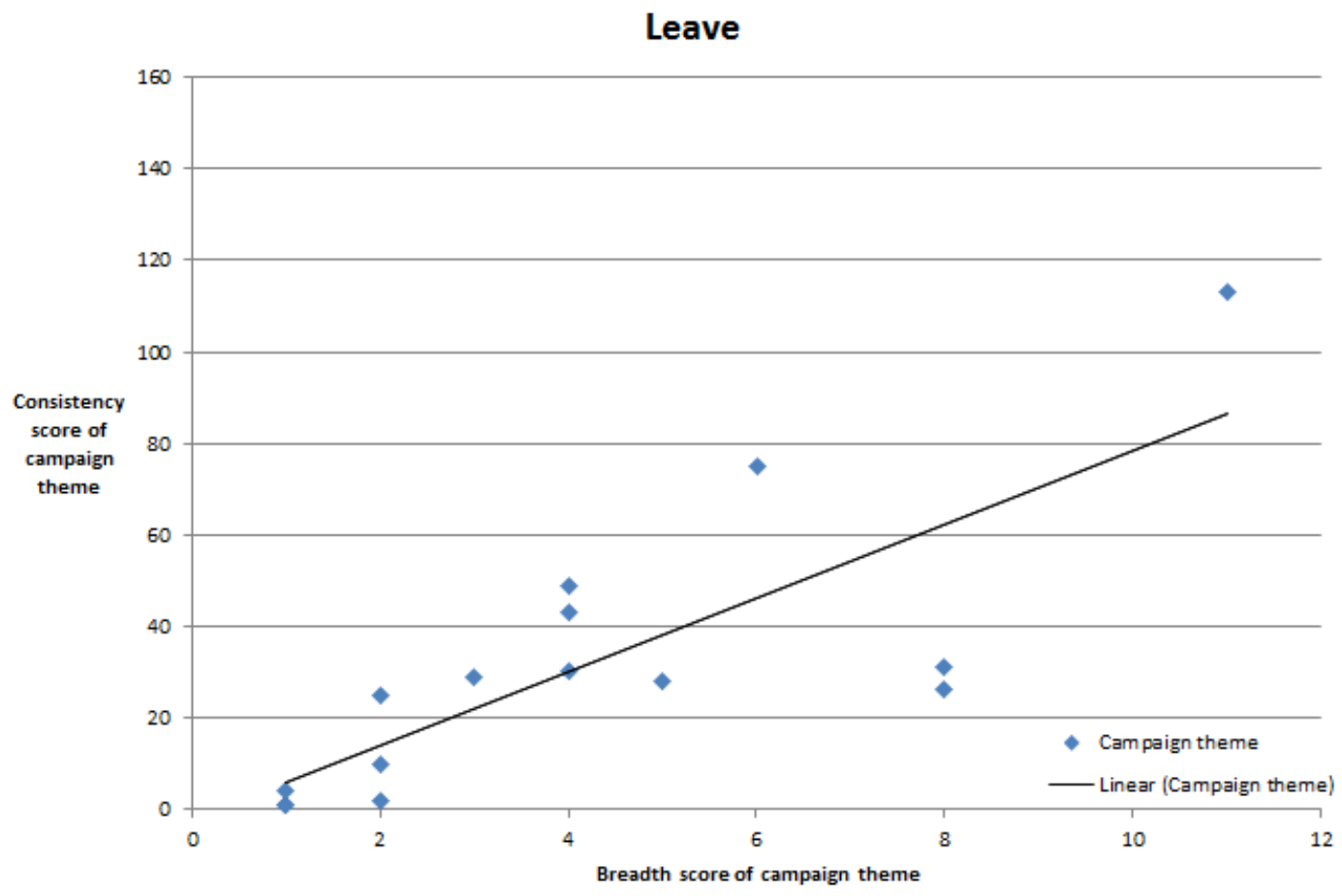

Figure 5-Breadth and consistency of Leave campaign themes being mentioned

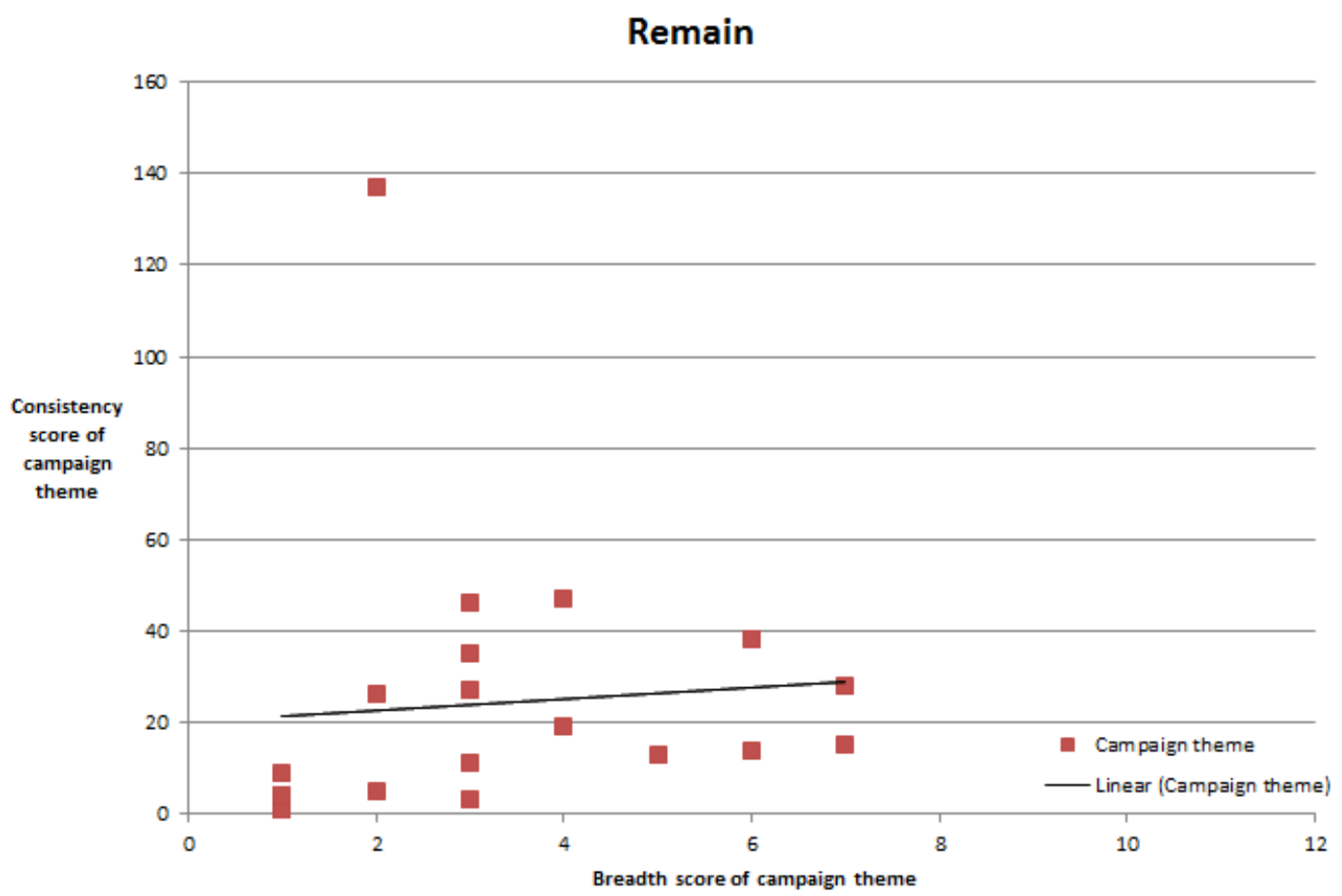

Figure 6-Breadth and consistency of Remain campaign themes being mentioned 
From Stage 2's campaign themes, results suggest that Remain identified a greater number of campaign themes that were unique to its case. Remain had more campaign themes (20) than Leave (15), and most of these were presented in a way that heightened their emotive content. From Table 3, 11 of these campaign themes were common to both campaigns, but others were unique to Remain ( 9 of 20) and to Leave (4 of 15) - suggesting Remain chased Leave's themes more with opposing positions. Also, Remain covered a greater number of campaign themes in debates (average 12.0 per debate) than Leave (10.3).

However, results suggest that Leave focused more on traction around their core messages and establishing consistent threads. For example, Leave covered a larger proportion of their campaign themes in each debate (68.9\%) than Remain (60.0\%) - and had more campaign themes that were focused on in all debates (5 of 15 campaign themes) than Remain ( 2 of 20). Also, Leave formed campaign themes: that contained, on average, more debate themes (9.3) than Remain (6.6); with a higher number of debate themes being involved (maximum 25) than Remain (15). Finally, Leave debaters were not as much led by the Remain campaign as they did not substantially respond to $45.0 \%$ of Remain campaign themes - while Remain did not address $26.6 \%$ of Leave campaign themes.

Comparing individual debaters and group debaters, individual debaters for Remain covered more campaign themes with their concepts (on average, one campaign theme covered every 4.8 minutes) than Leave (6.1), and group debaters from the different sides covered the same amount as each other but less than individuals (one every 8.1 minutes). However, Leave debaters covered a greater proportion of available campaign themes in each debate (60.0\% individual; $77.8 \%$ group) than Remain (58.8\% individual; $61.7 \%$ group).

From Stage 3's analysis of campaign sub-themes, results suggest that (over all debates) Leave developed campaign themes that had a more consistent threads. For example, Figures $5 \& 6$ show the difference between campaigns in terms of the breadth and consistency of campaign themes. In Figures $5 \& 6$, the breadth score is the number of campaign sub-themes in a campaign theme, while the consistency score measures how campaign themes are made up of a number of campaign sub-themes that are made up of debate themes i.e. to what extent campaign sub-themes are mentioned prolifically across debates. Figures $5 \& 6$ shows a distinction between the campaigns in terms of the higher consistency measure of the campaign themes for Leave evident through the presence of only 5 campaign themes for Leave (33.3\% in Figure 5) with a low consistency score of under 20, compared to Remain's 12 campaign themes under 20 (60.0\% in Figure 6). Also, it shows a higher number of campaign sub-themes being involved by Leave (maximum 11) than Remain (7), and shows that Leave 
offered more breadth in each of their campaign themes (average 4.1 campaign sub-themes per campaign theme) than Remain (3.3).

\section{Leave}

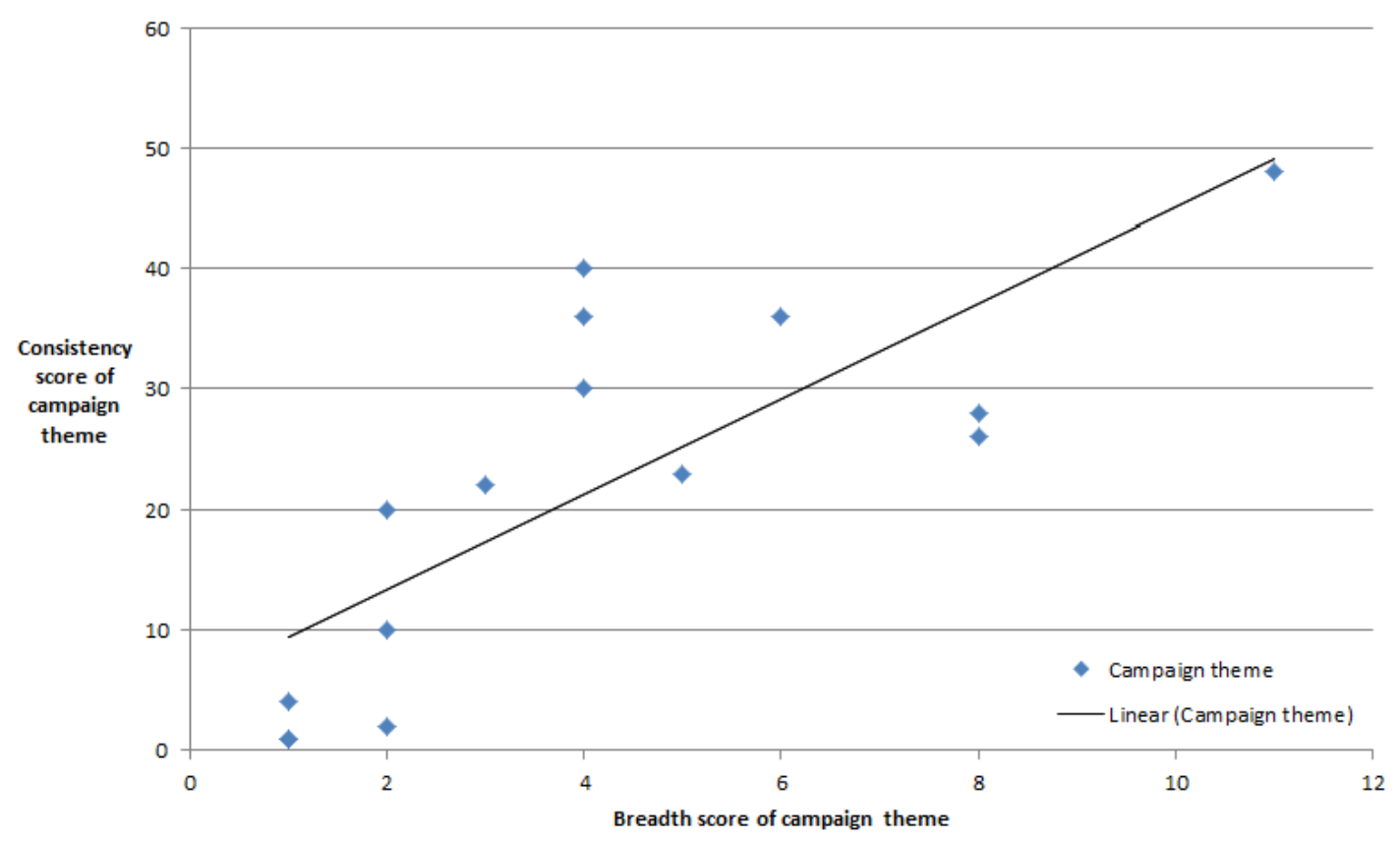

Figure 7-Breadth and consistency of Leave campaign themes being mentioned in different debates

\section{Remain}

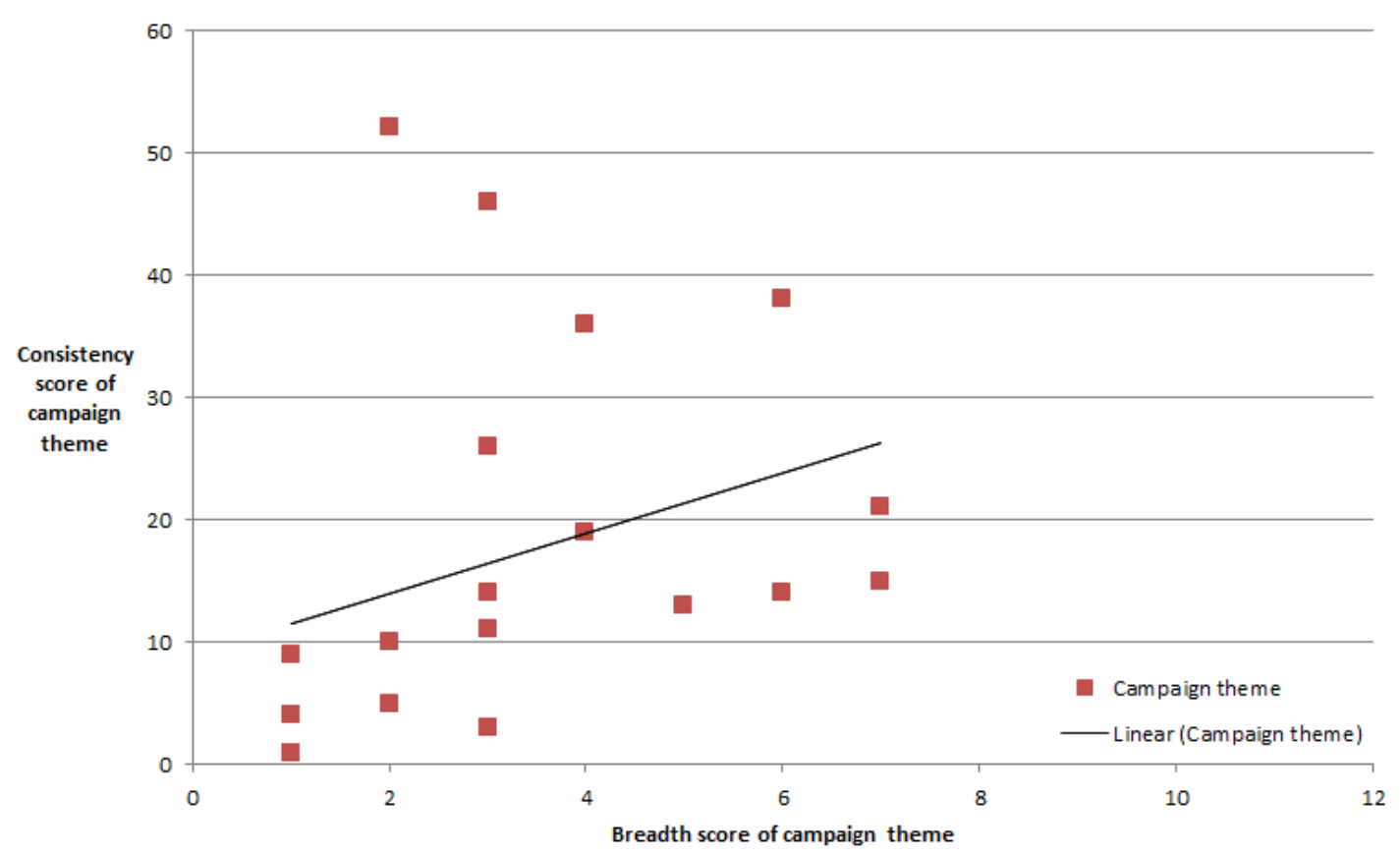

Figure 8-Breadth and consistency of Remain campaign themes being mentioned in different debates 
Figures $7 \& 8$ shows the breadth and consistency of campaign themes when repeated campaign subthemes from the same debate are eliminated i.e. assessing in how many debates campaign subthemes were mentioned. Here, a similar profile is found as Leave built more consistent campaign themes across debates than Remain e.g. only 5 themes (33.3\% in Figure 7) for Leave had a consistency score of under 20, compared to Remain's 14 campaign themes (70.0\% in Figure 8).

These results are supported from the analysis using the framework in Table 2. Of the six types of campaign theme found in the data, four types formed messages of low consistency (Types 1-4). From Table 2, Remain had more campaign themes in these low consistency categories (65.0\%) than Leave (33.3\%), but a similar amount to Leave in the category of 'somewhat consistent message' (Remain $25.0 \%$; Leave $26.7 \%$ ). Leave had a larger proportion of campaign themes that formed a 'very consistent message' (40.0\%) than Leave (10.0\%).

Taking all our analyses together, Leave established better levels of traction and consistency by focusing on a smaller set of core issues but looked at those with more breadth. Leave diverted better onto core issues by not responding to many of Remain themes - in contrast to Remain which responded to most of Leave's issues. Both sides took opposing positions to undermine each others' arguments and promote their own views especially on emotive issues. Leave was better at establishing consistent threads and campaign sub-themes that ran through the debates.

\section{Discussion}

Here we discuss our four aims for this paper, to show the novelty in our approach, we discuss our methodological, replicability and philosophical aims. Finally, we consider the context and a potential reason for the Brexit outcome in our modelling complexity section.

On our methodological aim (Aim 1), we had to adapt elements of causal mapping to accommodate the secondary and longitudinal characteristics of our data. For example, typically a soft OR model forms a boundary object between a facilitator and participants to create shared meaning, understanding and/or interests (Franco, 2013). However, our maps do not aim to achieve any of these, instead they represent how each side defined issues to influence voters and explore a decision space to post-rationalise what was said. Like Eden \& Ackermann (2004, p623) who experienced a similar challenge "[our] resultant maps did not truly represent cognition but rather a deliberately contrived argument" that was identified by the coder using secondary data and converted into our modelling language. 
The limitations of our data also meant we could not map how the arguments were received by voters, for example, we could identify emotive issues being raised but could not evaluate their effect on voters. Consequently, we focused on mapping the argument that was given by debaters and the validation of coding this argument in the map was challenging because we had no access to those from whom the data originated (like Eden \& Ackermann, 2004). Typically soft OR models are built by facilitators based on data collected from participants (Franco \& Montibeller, 2010) and validation can be done by asking participants. Thus, soft OR model validation is normally through collaborative inquiry (Champion \& Wilson, 2010), but this was not available here as we could not access debaters. We solved such issues by building legitimacy of the process (Champion \& Stowell, 2003) through creating explicit coding schemes and applying those consistently through investigator triangulation (Denzin, 1970). For example, we critiqued maps in Stage 1 to ensure consistent interpretation of debate themes; defined campaign themes in Stage 2 and identified which debate themes belonged in each; developed the rules behind the coding framework in Table 2 (Stage 3). To enhance confidence, two researchers coded every aspect and so tight rules were developed until both were satisfied that they (and others) would code the data the same. For example, in Stage 3 we identified campaign subthemes and how these built longitudinally and the coding was done twice without comparing them to ensure the coding system was robust and the codes were consistent. When not all codings matched, the coding scheme was altered to develop increasingly tight and specific definitions. This was labour intensive but (similar to Ackermann et al (1997) who had a protracted validation process by the analysts) we developed a consistency in our analysis that is beyond that we have previously achieved from participant validation (as participants may satisfice if the reward for precision is low). Furthermore, while we presented the analysis as moving through Stage 1-3 in a linear form, in reality the process was more complex as we fed our learning back into previous stages of analysis to tighten definitions and check coding schemes for consistency.

Our last methodological issue is longitudinal analysis. As more authors (and reviewers) realise the quality of insights possible from longitudinal analysis and the improved confidence this provides in results (Guba \& Lincoln, 1989), soft OR methods can be positioned to offer new analytical methods. Typically soft OR produces an artefact that is valid at a specific time (Checkland \& Holwell, 1998) and, so, longitudinal analysis requires many models built over a timeframe to identify changes. New techniques are required to compare such models. Currently soft OR does not have these techniques as comparison of models is typically confined to evaluation of the intervention (Midgley et al., 2013; Rouwette, Bastings, \& Blokker, 2010), not the model's content (Shaw, 2003). Therefore, new techniques are needed to analyse Soft OR models longitudinally and, while Barr et al (1992) offers some principles for changes in mental models over time, a wider range of techniques are needed to 
take into account other applications. We have presented some options but, for longitudinal analysis to prevail in soft OR, techniques should work for different modelling approaches and offer an array of comparisons over time. One hesitation on using soft OR for longitudinal studies could be the nature of the access needed to participants which is difficult enough for one intervention (Westcombe, Franco \& Shaw, 2006) but more difficult if required over time. To overcome this and to design and test analytical techniques, we moved away from primary data collection to exploit secondary data which is more easily accessible. Of course, a consequence of using secondary data is that the impact of the soft OR analysis would be different to current types of impact e.g. may have to look at a macro societal level impact, not just focussed on one group or organisation.

On our replicability aim (Aim 2), Brexit is a well-known topic and soft OR tools (and causal mapping) are widespread (Ranyard, Fildes \& Tun-I, 2015) and taught within many OR courses. While Hindle (2011) provides a written case study aimed at beginners, Brexit offers a more advanced case that requires working with video data. It is possible for teachers to allocate students a Brexit debate and ask them to map a Leave or Remain argument using debates available on YouTube - providing more realism than a written case. If this was done across 13 (groups of) students - one mapping a debate from either side - then the class would have an equivalent of our Stage 1 maps structured around debate themes. Those debate themes could be analysed in class discussion to identify campaign themes across the 13 maps (our Stage 2). Asking students to take these 13 maps and a selection of campaign themes could exercise students in recoding the debate themes into campaign sub-themes. Students would experience the known difficulties of causal mapping (e.g. developing craft skills to map consistently) (Keys, 2006; Ackermann, 2011) but the data source may help here (e.g. allowing repeated listening to the debate) as could previous knowledge of Brexit (allowing students to focus on coding technique rather than trying to understand the context). Students would also experience the challenges associated with analysing secondary data (e.g. no external validation, defining themes) where teacher support may be required. Some students may have an informed and closely held view on Brexit which should enhance their interest in the case and their appreciation of how causal mapping works (Carreras \& Kaur, 2011), but also require them to detach their modelling from that allowing for class discussion on such challenges. More information on the teaching case is provided in a supplementary file which includes guidelines on how a teaching session could be organised along with 2 debate maps and 4 campaign maps (two each from Leave and Remain) which detail the analysis.

On our philosophical aim (Aim 3), by not having a participant group we decapitated the essence of the soft OR research process as we had no recall to debaters to validate the content of the maps, thus were unable to validate our models through a constructivist approach (Guba and Lincoln, 1989). Thus, 
using secondary data had moved our application of causal mapping away from its normal philosophical justification (constructivism) and challenged us to explore alternative justifications that accommodated the absence of a socially constructed reality (Rutkowski \& Smits, 2001). We considered other philosophical positions close to constructivism (e.g. constructionism and postmodernism) which ontologically are subjective and thereby accept what is known is relative (Johnson \& Duberley, 2000). However, we needed a philosophical position that would justify our reliance on secondary data considering our detachment from it i.e. the debates only reflected, in a realist sense, what was said by both campaigns. By viewing our secondary data this way, ontologically we were moving closer to realism. However, realism was incompatible with our research process in not accommodating the existence of an independent social reality (Bhaskar, 1975) - which was essential due to the qualitative analysis we had done, were doing and were considering doing (Riege, 2003).

Ontologically, Bhaskar's critical realism (CR) (Bhaskar, 1975, 1979) better explained our study in defending the existence of a world that can be empirically observed along with understanding of that world through human meaning and explanation. CR bridges the objective world and social sciences by advocating the existence of independent social reality (Mingers et al, 2013), albeit starting from a premise that our knowledge of it is fallible in being influenced contextually by historical context (Johnson and Duberly, 2000).

To show CR's potential suitability for this study, we (very briefly) show how our study aligns to five aspects of CR: structured activities, generative mechanisms, logic of inference, open systems, and multi-methodology. In the sense that CR is 'realist', it accepts the presence of an independent social reality and suggests that this can be viewed through structured activities (Bhasker, 1979) such as communication (e.g. language), experiences (e.g. public observation) and events (e.g. debates), and the aim is to gain objective understanding from those (Mingers, 2000). In the sense that CR is 'critical', it accepts that the structured activities can be viewed differently as social events (epistemic relativity) (Mingers, Mutch \& Willcocks, 2013) e.g. that the Leave and Remain campaigns viewed the context of Brexit differently and that voters can be influenced by those differences through what was said in the debates. In analysing for these themes, we have analysed for what CR calls 'generative mechanisms' (Bhaskar 1978) i.e. underlying mechanisms which generate responses in the world - in our case the presentation of themes/arguments which may influence voters. The logic of inference underpinning CR is called retroduction which is a process of socially constructed human activity where a researcher moves between the observation of the empirical (as seen through structured activities) to create explanation that provides insight, potentially aiming to indicate the presence of un(realised) mechanisms and their interaction in the context (Zachariadis, Scott \& Barrett, 2013). Furthermore, 
inference takes place in an open system meaning that $C R$ creates inference about the mechanisms but not on their impact on the world. This is because the world will be changed by many (un)realised mechanisms operating simultaneously (e.g. a referendum vote cast may be as a result of any number of mechanisms - known and unknown) (Bhaskar, 1975). This is consistent with our approach of focusing on what was said during debates, not on the consequences of that. CR promotes multimethodology to build understanding, thus legitimises our more situated narrative analysis of the case (Stage 4) alongside a more reductionist (quantitative based) treatment (Stages 1-3) to build descriptions of the data (Zachariadis, Scott \& Barret, 2013).

The benefits to our study from relating to $C R$ include the ability to loosen the ontological and epistemological ties of being wedded to constructivism or positivism without losing rigour which, methodologically, opens the study more to a multi-methods research design. Thus, CR enables the researcher to analyse phenomena from multiple methodological perspectives and create explanation, proposition and hypothesis (Zacharidas et al, 2013), thereby challenge the boundaries of a constructivist or positivist approach. Thus, we uncover some of the underlying mechanisms of Brexit showing insight, explanation and proposition of the interplay between historically and contextually specific narrative with statistical description (Zacharidas et al, 2013). CR also offers the foundations from which we can hypotheses from the findings with strengths of multi-methodological data that are not possible from only interpretivism. We limit the discussion of Aim 3 to showing the general applicability of CR to our study - realising that this provides a brief insight to CR. Our intention here is to continue Mingers (2000) discussion on CR as a key methodological approach for soft OR.

Our fourth aim, modelling complexity, is to explain how our analytical methods could identify differences in the campaigns' debate performance. First, we investigated the contributions made during debates and this identified the first differences in performance of the campaigns. Remain's greater volume of contributions converted into more debate themes and more information in each debate theme. It is only with hindsight that we realise this may not have been a winning strategy as Johnson (2009) notes "With so many simultaneous, competing efforts to move an audience, confusion is more likely than not" (p41). This could have compromised the impact of the message, as Winston Churchill said "there is nothing that gives greater pleasure to a speaker than seeing his great points go home. It is like the bullet that strikes the body of the victim." (28 April 1927)

Second, we examined campaign level insights by exploring the themes that ran across the debates. Here, we focused on how campaign themes gained traction on core messages and built substantial argument around those, especially centring on emotive content. By focusing on fewer campaign themes, Leave built themes that were more substantial. By focusing on their core issues, Leave were 
not taken off message by chasing or opposing Remain's themes and thereby talking about Remain's issues. In contrast, Remain followed Leave by attempting to oppose their arguments but, as Winston Churchill said "You will never reach your destination if you stop and throw stones at every dog that barks" (3rd December 1923).

Lastly, we examined the consistency of the messages across the debates thereby exploiting the longitudinal nature of the data. Our analysis found that Leave had stronger consistent threads across debates by expanding campaign themes across debates. Leave followed Winston Churchill's advice: "If you have an important point to make, don't try to be subtle or clever. Use a pile driver. Hit the point once. Then come back and hit it again. Then hit it a third time-a tremendous whack". This constant focus by Leave propagated an emotive message of take back control throughout many themes. In contrast, the messages from Remain were multi-faceted and void of a strong consistent thread, potentially moving the voters in too many directions for a message to resonate clearly and frequently.

From this study, four research questions for further work include: (1) Can the measure of consistency be applied to exploring the content of causal maps from single workshops, or is it unique to longitudinal data? We have shown that consistency can be analysed across different debates but it may also be evident in a single day-long workshop. For example, groups may shift their perspectives on a theme, beginning the day with one view but ending the day with a fuller and different view. This could be evident through the analyses methods presented in this paper. (2) What new content-related measures of causal maps can offer novel longitudinal insights? The analyses presented here may be complemented by other approaches which explore, for example, person-level analysis of themes, how answers are shaped towards specific debate questions, and how the mainstream media report on the content of debates compared to what was actually said. (3) What other sorts of secondary data could be causally mapped using soft OR techniques? We believe that any data that contains causal inferences can be mapped using soft OR techniques but some sorts of secondary data may allow those inferences to be more apparent than others. For example, documents as secondary data may be more or less difficult to evaluate than debates and further work could differentiate between these sources. (4) What themes would other qualitative research approaches identify for the Leave and Remain campaigns? While other soft OR and qualitative data analysis techniques should identify the same themes from the debates as causal mapping, the publicly accessible nature of the data allows this question to be answered by applying different techniques to the data and comparing the results. We now conclude the paper.

\section{Conclusions}


This paper has explored a new topic for soft OR through the analysis of publicly available secondary data that is longitudinal. This has required new approaches to analyse the changing arguments which run throughout causal maps from over a month of debate. Instead of focusing on usual means of analysing causal maps (looking at the intrinsic properties of the maps), we have exploited the benefits of the longitudinal dataset to understand how campaign themes are built across causal maps, how these are constructed differently at different points in time, how consistency across debates can be analyse, how dominant threads run across debates, and how Leave and Remain differed in their approach.

The title of this paper questions why Brexit happened and, from the selected debates alone, our analysis suggests that part of an answer may rest on the voters being presented with a more consistent Leave message throughout the debates. We have found that Leave presented a more consistent message as they focused on their key battleground messages, covered fewer themes, were not distracted by Leave's campaigns, built arguments across the televised debates, and constantly drove home key threads running through most themes. We have not evaluated the accuracy of content provided by either campaign, nor the charisma of the debater, nor the level of emotion created in voters by the debates, nor how the messages created opinion change in voters, nor the plethora of other data available such as newspaper articles, social media and radio programmes. Nevertheless, Leave's consistency can be seen in other aspects of their campaign, for example, they fielded the same group of debaters in Debates 5 \& 9 (Table 1) which were the longest and (arguably) most significant debates. In contrast, Remain fielded 6 different campaign members - none of whom had participated in similar Brexit debates on mainstream media.

Since the referendum, much has happened across all campaign themes identified from the debates. There has been significant uncertainty about each theme which will likely continue through UK's activation of (the now infamous) Article 50 until its eventual full withdrawal from the EU and thereafter. There continues to be a huge amount of qualitative data being disseminated and the possibility of collecting and analysing these longitudinally continues to offer possibilities for the development of new analytical techniques. Soft OR techniques are well-placed to knit together the complex messages these contain and, through confronting the complexities of these, developing new methods for the analyses of different sorts of longitudinal data as well as the validation of soft OR models.

"We cannot afford - we have no right - to look back. We must look forward"

Winston Churchill, 10 December 1936

\section{References}


Ackermann, F., Eden, C., \& Williams, T. (1997). Modeling for Litigation: Mixing Qualitative and Quantitative Approaches. Interfaces, 27(2), 48-65.

Ackermann, F., (2011) Getting "Messy" with Problems: The Challenges of Teaching "Soft" OR. INFORMS Transactions on Education, 12(1), 55-64.

Ackermann, F., Howick, S., Quigley, J., Walls, L., \& Houghton, T. (2014). Systemic risk elicitation: Using causal maps to engage stakeholders and build a comprehensive view of risks. European Journal of Operational Research, 238, 290-299.

Anderson, C.J. and Reichert, M.S., 1995. Economic benefits and support for membership in the EU: A cross-national analysis. Journal of Public Policy, 15(3), 231-249.

Ansell, C., 2000. The networked polity: Regional development in Western Europe. Governance, 13(2), 279-291.

Bailes, A.J., 2008. The EU and a 'better world': what role for the European Security and Defence Policy? International Affairs, 84(1), 115-130.

Barr, P. S., Stimpert, J. L., and Huff, A. S. (1992) Cognitive Change, Strategic Action, and Organizational Renewal. Strategic Management Journal, 13, 15-36.

Bhaskar, R. 1975. A Realist Theory of Science, Leeds, UK: Leeds Books.

Bhaskar, R. 1978. A Realist Theory of Science, Hemel Hempstead: Harvester.

Bhaskar, R. 1979. The Possibility of Naturalism, Sussex, UK: Harvester Press.

Benoit, W. L., Hansen, G. J., \& Verser, R. M. (2003). A meta-analysis of the effects of viewing U.S. presidential debates. Communication Monographs, 70(4), 335-350.

Benoit WL and Tamir Sheafer (2006) Functional Theory and Political Discourse: Televised debates in Israel and the United States, 83(2), 281-297.

Carreras, A.L., \& Kaur, P., (2011) Teaching Problem Structuring Methods: Improving Understanding Through Meaningful Learning. INFORMS Transactions on Education, 12(1), 20-30.

Carlin, D. B. (2000). Watching the debates: A guide for viewers. In S. Coleman and D. Butler (Ed.), Televised election debates (pp. 157-177). St. Martin's Press: New York.

Champion, D., \& Stowell, F. A. (2003). Validating Action Research eld studies : PEArL. Systems Practice and Action Research, 16(1), 21-36.

Champion, D., \& Wilson, J. M. (2010). The impact of contingency factors on validation of problem structuring methods. The Journal of the Operational Research Society, 61(9), 1420-1431.

Checkland, P., \& Holwell, S. (1998). Action Research : Its Nature and Validity. Systems Practice and Action Research, 11(1), 9-21.

Checkland, P., \& Poulter, J. (2010). Systems Approaches to Managing Change: A Practical Guide. (M. Reynolds \& S. Holwell, Eds. Springer: London.

Checkland, P., \& Scholes, J. (1999). Soft Systems Methodology in Action. John Wiley and Sons Ltd: Chichester. 
Checkland, P. (1985). From Optimizing to Learning: A Development of Systems Thinking for the 1990s. The Journal of the Operational Research Society, 36(9), 757-767.

Cho, J., and S. P. Choy. (2011).From podium to living room: Elite debates as an emotional catalysts for citizen communicative engagements. Communication Research, 38(6), 778-804.

De Grauwe, P., 2006. What have we learnt about monetary integration since the Maastricht Treaty?. JCMS: Journal of Common Market Studies, 44(4), 711-730.

Denzin, N. K. (1970). The Research Act in Sociology. Aldine: Chicago, IL.

Eden, C. (1988). Cognitive Mapping. European Journal of Operational Research (36), 1-13.

Eden, C. (2004). Analyzing cognitive maps to help structure issues or problems. European Journal of Operational Research, 159(3), 673-686.

Eden, C. and Ackermann, F. (2004) Cognitive Mapping Expert Views for Policy Analysis in the Public Sector. European Journal of Operational Research, 152,615-630.

Feldstein, M., (2012). The failure of the euro. Foreign Affairs, 91(1), 105-116.

Fligstein, N. and Stone Sweet, A., 2001. Institutionalizing the Treaty of Rome. The institutionalization of Europe, 29-55.

Franco, L. A. (2013). Rethinking Soft OR interventions: Models as boundary objects. European Journal of Operational Research. 231(3), 720-733.

Franco, L. A., \& Montibeller, G. (2010). Facilitated modelling in operational research. European Journal of Operational Research, 205(3), 489-500.

Gottfried J.A., Hardy B.W., Holbert R.L., Winneg K.M. \& Jamieson K.H. (2016): The Changing Nature of Political Debate Consumption: Social Media, Multitasking, and Knowledge Acquisition, Political Communication. Journal of Political Communication. Forthcoming.

Grebelsky-Lichtman, T. (2015). The Role of Verbal and Nonverbal Behavior in Televised Political Debates. Journal of Political Marketing: 1-26.

Grieco, J.M., 1995. The Maastricht Treaty, Economic and Monetary Union and the neo-realist research programme. Review of International Studies, 21(1), 21-40.

Guba, E.G., \& Lincoln, Y.S., (1989). Fourth Generation Evaluation. Newbury Park, CA: Sage.

Hindle, G.A., (2011) Case Article - Teaching Soft Systems Methodology and a Blueprint for a Module. INFORMS Transactions on Education, 12(1), 31-40.

Holden, M. and Garrod, D., 1996. The Common Fisheries Policy: origin, evaluation and future. Fishing News Books Ltd.

Jackson, M. C. (2006). Beyond problem structuring methods: reinventing the future of OR/MS. The Journal of the Operational Research Society, 57(7), 868-878.

Jackson, M. C., \& Keys, P. (1984). Towards a System of Systems Methodologies. The Journal of the Operational Research Society, 35(6), 473- 486.

Johnson S.L. (2009) Winning debates: A guide to debating in the style of the World Universities Debating Championships. International Debate Education Association: New York, NY. 
Johnson, P. and Duberley, J., (2000). Understanding management research: An introduction to epistemology. Sage.

Kelly, G. A. (1955). The Psychology of Personal Constructs: A Theory of Personality. Norton, New York.

Keys, P. (2006). On Becoming Expert in the Use of Problems Structuring Methods. The Journal of the Operational Research Society. 57(7), 822-829.

Knox, P., Agnew, J.A. and McCarthy, L., (2014). The geography of the world economy. Routledge.

Lejour, A. and De Mooij, R.A., (2001). EU enlargement: Economic implications for countries and industries. CESifo Working Paper Series No. 585.

Lutz, H., (2002). The long shadows of the past. The new Europe at a crossroad. In Crossing borders and shifting boundaries (pp. 57-73). VS Verlag für Sozialwissenschaften

McCormick, J., (2014). Understanding the European Union: A concise introduction. Palgrave Macmillan.

Midgley, G., Cavana, R.Y., Brocklesby, J., Foote, J.L., Wood, D.R.R., and Ahuriri-Driscoll, A. (2013). Towards a new framework for evaluating systemic problem structuring methods. European Journal of Operational Research, 229(1), 143-154.

Mingers, J., Mutch, A., and Willcocks, L., (2013). Critical realism in information systems research, MIS Quarterly 37(3), 795-802.

Mingers, J. (2000). The contribution of critical realism as an underpinning philosophy for OR/MS and Systems, The Journal of the Operational Research Society 51(11), 1256-1270.

Moyer, W. and Josling, T., (2002). Agricultural policy reform: politics and process in the EU and US in the 1990s. Ashgate Publishing Ltd.

Nugent, N., (2010). The government and politics of the European Union. Palgrave Macmillan.

Puetter, U., (2012). Europe's deliberative intergovernmentalism: the role of the Council and European Council in EU economic governance. Journal of European Public Policy. 19(2), 161-178.

Ranyard J.C., Fildes R. and Tun-I H., (2015). Reassessing the scope of OR practice: The Influences of Problem Structuring Methods and the Analytics Movement. European Journal of Operational Research. 245,1-13.

Riege, A.M., (2003). Validity and reliability tests in case study research: a literature review with "handson" applications for each research phase. Qualitative Market Research: An International Journal, 6(2), 75-86.

Rosenhead, J., and Mingers, J., (2001). Rational Analysis for a Problematic World Revisited. Chichester: Wiley.

Rouwette, E., Bastings, I., and Blokker, H., (2010). A Comparison of Group Model Building and Strategic Options Development and Analysis. Group Decision and Negotiation, 20(6), 781-803.

Rutkowski, A-F., and Smits, M., (2001). Constructionist theory to explain effects of GDSS. Group Decision and Negotiation 10(1),67-82.

Schroeder, A., (1996). Watching between the Lines: Presidential Debates as Television. The International Journal of Press/Politics, (1)4, 57-75. 
Schroeder, A., (2008). The Presidential Debates: Fifty Years of High Risk TV. Columbia University Press

Shaw, D., (2003). Evaluating electronic workshops through analysing the 'brainstormed' ideas. Journal of the Operational Research Society. 54(7), 692-705.

Strauss, A., and Corbin, J., (1998). Basics of qualitative research: Techniques and procedures for developing grounded theory. Sage Publications.

Van Herk, H., Poortinga, Y.H. and Verhallen, T.M., (2004). Response styles in rating scales evidence of method bias in data from six EU countries. Journal of Cross-Cultural Psychology. 35(3), 346-360.

Vergeer, M., and Franses P.H., (2016). Live audience responses to live televised election debates: time series analysis of issue salience and party salience on audience behavior. Information, Communication \& Society. 19(10), 1390-1410.

Vinciarelli, A., Dielmann, A., Favre, S. and Salamin H., (2009). Canal9: A database of political debates for analysis of social interactions. 3rd International Conference on Affective Computing and Intelligent Interaction and Workshops. 10-12 September. Amsterdam, Netherlands.

Westcombe, M., Franco, L.A. and Shaw, D., (2006). Where next for PSMs-A grassroots revolution? Journal of the Operational Research Society, 57, $776-778$.

Williams, T., Ackermann, F. and Eden, C (2003). Structuring a delay and disruption claim: An application of cause-mapping and system dynamics, European Journal of Operational Research, 148, 192-204.

Work, W. and Boileau, D. M., (1985). Television debates. Communication Education. 34(4), 369-375.

Zachariadis, M., Scott, S., and Barrett, M., (2013). Methodological Implications of Critical Realism for Mixed-Methods Research, MIS Quarterly 37(3), 855-879. 